\title{
The Manifestations of Mediterranean Diet in Egyptian Intangible Cultural Heritage
}

\author{
Mohamed Amer ${ }^{1}$ and Azza Abdel Maksood ${ }^{2}$
}

\begin{abstract}
The Mediterranean diet was inscribed in 2013 on the UNESCO Intangible Cultural Heritage (ICH) list. It is considered knowledgably a life style including a group of activities. Although this inscription was exclusively restricted in some European states, this mixed or connected-separated kind of a living heritage is not well-recognized in Egypt. It has been estimated by the researcher some examples of Egyptian countries, cities or governorates where people indirectly apply the Mediterranean diet including various actions such as a traditional food, crafts, social practices and construction. The researcher puts a good strategy to preserve it along the future generations and to invest it developing the local socio-economic context. Finally, the researcher presents the recommendations linking culturally and economically between the Mediterranean diet-related activities and the Egyptian cultural identity. Respectively, this linkage contributes raising an awareness of the Egyptian local community for the cultural significance of ICH and pushing them, as an initial inventory body, to preserve their heritage and operationalize the factor of sustainability through the transformation process of the cultural heritage knowledge.
\end{abstract}

\section{Keywords:}

Egyptian Traditional Lifestyle - UNESCO Intangible Cultural Heritage List - Popular Practices - Heritage Economic - the Mediterranean Diet

\section{Introduction:}

The local community is mainly the representative of intangible cultural heritage (ICH). ICH is an expression for the local cultural identity which reflects the socio-economic form of the local community. It is included a group of skills, thoughts, and the popular imaginary forms such as myths, and narratives. ${ }^{3}$ As a result of the globalization and modernization waves, the authentic value of ICH faces currently a great challenge surviving and transmitting along the upcoming generations. Thus, "the problem of authenticity in [ICH] cannot be solved by isolating a single form of performance of a given practice since this would require an infinite listing of its historical, political, social, artistic and symbolic ontology"4.

The Mediterranean Diet (MD) is a traditional lifestyle aspect that was inscribed on UNESCO ICH list in 2010 between Spain, Greece, Italy, and Morocco; and then, was extended in 2013 adding Croatia, Cyprus and Portugal. This aspect requires a group of actions which are represented throughout craftsmanship, social practices, construction and its conservation. It has a great

\footnotetext{
${ }^{1}$ Heritage Management Professional, Founder of "Heritage For All” Initiative.

${ }^{2}$ Curator, National Museum of Egyptian Civilization, Museums Sector, Egyptian Ministry of Antiquities.

${ }^{3}$ Jesús Antonio Machuca, “Challenges for Anthropological Research on Intangible Cultural Heritage,” in Anthropological Perspectives on Intangible Cultural Heritage, ed. Lourdes Arizpe and Cristina Amescua, vol. 6, Springer Briefs in Environment, Security, Development and Peace (New York: Springer and Centro Regional de Investigaciones, Universidad Nacional Autónoma de México, 2013), 57-59.

${ }^{4}$ Lourdes Arizpe, "Singularity and Micro-Regional Strategies in Intangible Cultural Heritage," in Anthropological Perspectives on Intangible Cultural Heritage, ed. Lourdes Arizpe and Cristina Amescua, vol. 6, Springer Briefs in Environment, Security, Development and Peace (New York: Springer and Centro Regional de Investigaciones, Universidad Nacional Autónoma de México, 2013), 20.
} 
part of cultural identity. It breaks down barriers among all categories of ages, genders, and social classes. ${ }^{5}$

Considering the common historiographical context, it is one of the cultural policy theme "BeniCultural" that to be represented in the cultural landscape viewing a multi historical layers of such civilization whose manifestations had been transmitted from generation to another generation according to their socio-economic requirements. ${ }^{6}$

Traditional food as a Beni Culturali, it has been revealed the socio-economic context and the history of each local community and the features of the cultural landscape transformation. It refers easily to the daily lifestyle of such community in various destinations and periods through their selection, production, distribution and consumption ways according to a group of factors such as income, prices, preferences, beliefs, and cultural traditions, the geographical, social and economic contexts. Thus, it manifests also the integrity of local traditions and the cultural identity. ${ }^{7}$

MD plays socially and culturally a great role strengthening sustainably the agro-food traditions. In 2007, Barcelona Declaration on MD as ICH referred to its cultural significance ensuring the sustainable agriculture and safeguarding the food security. MD is an integrated theme which ensures, through a documental and managerial process or in the other words through the sustainable development, the continuity of interacting between the land or the cultural landscape and the indigenous residents by the preservation and development of traditional practices. Its traditions have ability to create intangibly a conversation space among a group of intercultural attitudes sharing the similar values. ${ }^{8}$

In 2010, nominating MD as ICH representative, UNESCO ICH committee has been referred stating and identifying the MD feature that "[MD] consists of a series of valuable traditional practices, knowledge and skills passed down from generation to generation that strengthen the sense of belonging and the continuity of the communities". Also, in 2007, Spain recognized MD, through its documents to the European Union Council of Ministers of Agriculture and Fisheries, as " a very important component of the cultural, social, territorial, environmental and gastronomic heritage of the countries and peoples in the region, historically forming part of a way of life."

MD is a multidisciplinary theme. In regard of modern culture, the term "Diet" is majorly used to refer therapeutically or aesthetically a food regime. Interpretively, the word "Diet" was derived from the Latin "Diaeta" that comes originally from the Greek "Díaita" which means "a lifestyle" wherever with individuals, families, communities or villages. It reflects mainly the Mediterranean lifestyle sharing the social, cultural, health and economic perspective of a traditional food. Thus, MD is not only a nutritional regime but also, to express the interaction between the human being, the natural context and the cultural landscape as well investing a group of talents, practices, and habits. MD states are joint in some nutritional ingredients, e.g. olive oil, cereals, vegetables, fish, dairy, meat, and spices; and culinary typologies such as cooking, boiling, and barbecuing. As a result of interacting with the surrounding cultural landscape, it has special characteristics including the consumption level of food and crops, the architectural maintenance, and conservation as well as the traditional craftsmanship such as fishing,

\footnotetext{
${ }^{5}$ Tullio Scovazzi, "Intangible Cultural Heritage as Defined in the 2003 UNESCO Convention," in Cultural Heritage and Value Creation: Towards New Pathways, ed. Gaetano M. Golinelli (London: Springer, 2015), 111; UNESCO ICH, “Mediterranean Diet,” UNESCO Intangible Cultural Heritage Committee, 2013, accessed August 12, 2017, https://ich.unesco.org/en/RL/mediterranean-diet-00884.

6 "Beni Culturali" - "The complex historical, intellectual and material products of human society (....) the wide range of values related to the natural function and the broad economic utility of products, including art." Massimo Montella, "Cultural Value," in Cultural Heritage and Value Creation: Towards New Pathways, ed. Gaetano M. Golinelli (London: Springer, 2015), 12, 14, 15, 17.

${ }^{7}$ Ibid., 18, 24; Martine Padilla, Zahra S. Ahmed, and Habiba H. Wassef, "In the Mediterranean Region: Overall Food Security in Quantitative Terms but Qualitative Insecurity?,” Analytic Note (Paris, France: International Center for Advanced Mediterranean Agronomic Studies (CIHEAM), 2005), 10, accessed May 20, 2017, http://portail2.reseau-concept.net/Upload/ciheam/fichiers/ANP4.pdf; Giovanni Scepi and Pier Luigi Petrillo, “The Cultural Dimension of the Mediterranean Diet as an Intangible Cultural Heritage of Humanity," in Cultural Heritage and Value Creation: Towards New Pathways, ed. Gaetano M. Golinelli (London: Springer, 2015), 173.

${ }^{8}$ Dernini, op. cit., 289; Scepi and Petrillo, op. cit., 178, 180.

${ }^{9}$ Ibid., 183; Dernini, op. cit., 288.
} 
cultivating, grazing, and harvesting. Therefore, there are a group of mutual dishes, social practices, and festive events and so on in the majority of these states. ${ }^{10}$

Women have a great role to transmit the cultural significance and the heritage knowledge of MD preserving its techniques, either in social context (families), in the apprenticeship context (craftsmanship), or in an educational context. "The conventional forms of knowledge transmission, implemented primarily by women, include young people's imitation of older individuals (....) through organized festivals, events and campaigns that disseminate the cultural heritage underlying [MD]." Providing that, UNESCO ICH (2003) ${ }^{11}$ recommends operationalizing the perspective of "revitalization" in order to solve the consequence of losing the traditions of parents and grandparents especially by the young generations. ${ }^{12}$

Inscribing MD theme on UNESCO ICH list combines between the material and immaterial heritage expressing the social and cultural identity. Traditionally, those who made these traditional dishes follow an ancient culinary typology which they historically inherited and transmitted the culinary procedures from generation to generation creating their cuisines. These were already existed in the classical globe (Jewish, Christian, or Muslim medieval dishes), the modern and contemporary ages mixing their ingredients and typologies with the America-origin cuisines especially during the $19^{\text {th }}$ and $20^{\text {th }}$ centuries. Traditionally, MD states and its cultures, representing the manifestations of the shared cultural identity, have joint ingredients - such as fats, seasonings, herbs, spices, cereals, wheat, beans, chickpeas, and lentils -, the secondary ingredients - e.g. meat, fish, vegetables and fruits - and culinary typologies such as pickling, roasting, cooking, breading, frying, and baking. ${ }^{13}$

MD contributes indirectly enhancing the cultural foundations which seek to guarantee socially and culturally the sustainability pattern of the cultural significance and/or identity of communities. Representing the MD context as ICH theme that to preserve the cultural value of gathering the families and individuals:

[MD] is on display every day and in a more spectacular and elaborate way during the festivities that mark the passing of the calendar year and religious (.....). These holidays are a communal projection of what occurs within individual family homes, revealing why activities often take place outdoors to witness the openness of the individual and the family to the rest of society and the community. One logical consequence is that social ties, including the feeling of neighborliness, reciprocity, sharing and conviviality, are strengthened during such mass celebrations (.....), facilitate social harmony, the rediscovery of common roots, and the development of ancient traditions. ${ }^{14}$

\footnotetext{
${ }^{10}$ Sandro Dernini, “The Strategic Proposal for the Candidacy of the Mediterranean Diet for Inclusion in the UNESCO List of Intangible Cultural Heritage," European Institute of the Mediterranean (IEMed.), 2008, 288, 289, accessed September 18, 2017, www.iemed.org/anuari/2008/aarticles/EN288. pdf; Pier Luigi Petrillo, “The Mediterranean Diet One Year after and the Role of UNESCO,” Italian Committee, The Special Agency PromImperia- The Italian Chamber of Commerce Committee, 2014, accessed September 17, 2017,www.promimperia.it/media/11311/wg1_1_eng_coordinator_ petrillo_mediterranean_diet_as_world_heritage.pdf; Massimiliano Rennaa, VitoAntonio Rinaldib, and Maria Gonnellaa, “The Mediterranean Diet between Traditional Foods and Human Health: The Culinary Example of Puglia (Southern Italy)," International Journal of Gastronomy and Food Science 2 (2015): 64; Scepi and Petrillo, op. cit., 174-76; Scovazzi, op. cit., 112.

${ }^{11}$ UNESCO, op. cit.

${ }^{12}$ Scepi and Petrillo, op. cit., 180; Scovazzi, op. cit., 112, 120, 122.

${ }^{13}$ Isabel González Turmo, “The Mediterranean Diet as a Heritage Object,” Quaderns de La Mediterrània 13 (2010): 46-48.; Scepi and Petrillo, op. cit., 171,172 .

${ }^{14}$ Ibid., 176, 177
} 


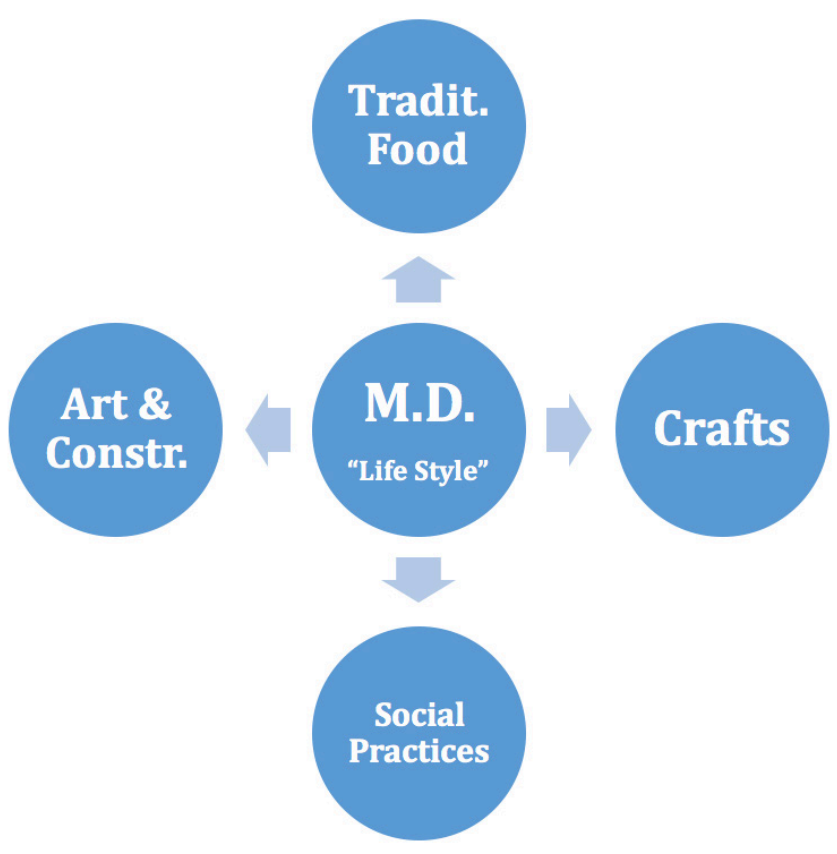

Diagram 1: The Mediterranean Diet Pillars

Source: adopted C UNESCO ICH Description of the Mediterranean Diet, https://ich.unesco.org/en/RI/mediterranean-diet-00884 [Accessed April 10, $2017]$.

Safeguarding MD, the four emblematical states (Spain, Italy, Greece and Morocco) had been developed the preservation measures guaranteeing the cultural diversity of the Mediterranean food heritage as a multi-national cultural regime; encouraging the scientific and artistic research projects; enhancing the educational initiatives and capacity building programs; raising an awareness of the local community especially the young generations. These preservation measures can effectively manage, promote, and transmit MD theme as ICH. ${ }^{15}$

Thus, the local communities ${ }^{16}$ at these initial four states played a great role. They prepared their proposal adopting a joint strategic plan that aims at strengthening MD and its role as a cultural and socio-economic model. Moreover, they launched, highlighting the global promotion of MD, initiatives calling the streets in each society to revive continually the memory commemorating each community members; as well as the following procedures:

1- The launch of a joint website;

2- The development and dissemination of a "dictionary" in the four official languages of the states involved (Italian, Spanish, Greek and Arabic) as well as in English and French;

3- The appointment of children in the four communities as MD ambassadors;

4- An annual celebration of the week of [MD], to be held every year in rotation in one offour symbolic communities. ${ }^{17}$

Linking between the traditional knowledge and the food security, the indigenous local communities invest their traditional experience guaranteeing their ecosystem livelihood. Therefore, it has been realized that this traditional knowledge has the effective facility of tackling the current problem and enhancing the socio-environmental sustainability. Respectively, farmers or

\footnotetext{
${ }^{15}$ Dernini, “The Strategic Proposal for the Candidacy of the Mediterranean Diet ....," 291.

${ }^{16}$ The four emblematic communities of Soria (Spain), Koroni (Greece), Chefchaouen (Morocco) and Cilento (Italy)

${ }^{17}$ Scepi and Petrillo, op. cit., 185, 186.
} 
fishers can preserve in-situ their genetic resources following the traditional lifestyles and safeguarding the food resources for the present and future generations. ${ }^{18}$

\section{The Mediterranean Diet: Sustainable Development and National Economic in Egypt}

Egypt has its nutritional system that to be based traditionally on the flood calendar of the Nile River. Therefore, the Egyptian diet was much depended on the cereals and the preserved food. Egyptians have inherited the ancient food preservation methods over the history. They can, till now, store cereals, cheese, fruits, fish, meat, and so on. The "know-how" concept had been transmitted to the present occupying agreat importance in the modern Egyptian diet and the food stores' composition especially inside the traditional constructions. ${ }^{19}$

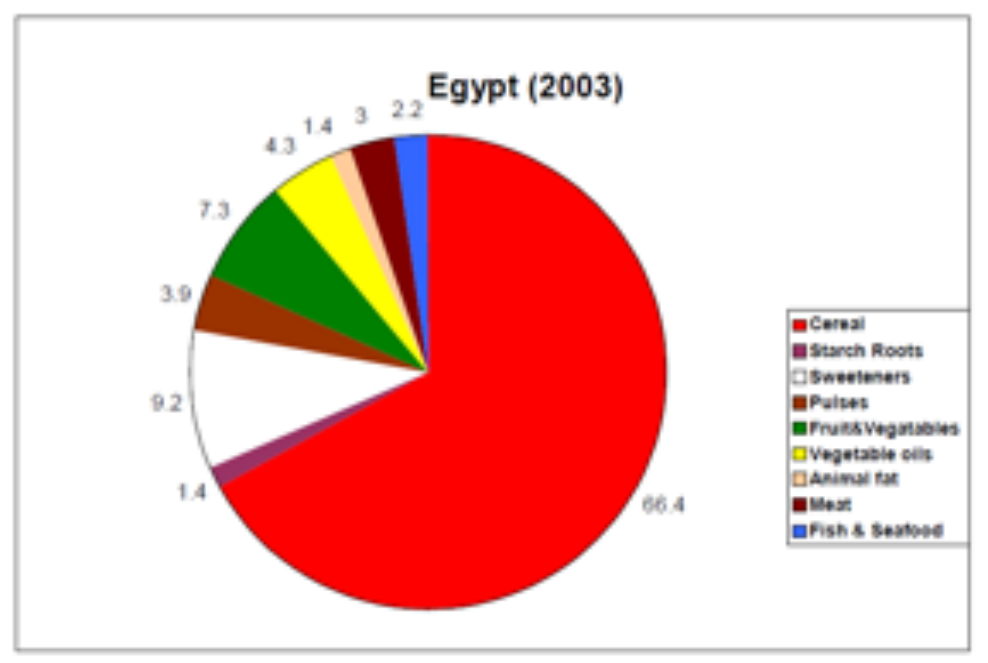

Figure 1: UN Food and Agriculture Organization - Statistical Databases - Nutrition Country Profile [Egypt, 2003] Source: Padilla et al. "In the Mediterranean Region: Overall Food Security in Quantitative Terms but Qualitative Insecurity?" Analytic Note. Paris, France: International Center for Advanced Mediterranean Agronomic Studies (CIHEAM), 2005, 11. Accessed May 20, 2017, http://portail2.reseau-concept.net/ Upload/ciheam/fichiers/ANP4.pdf.

Through the features of MD, the traditional nutritional Egyptian system include many ingredients of the Mediterranean basin such as cereals, vegetables, fruits, cheese, oils and white and red meat. Also, the authority has to recognize a significant characteristic that the Egyptian meal is mainly based on bread as ghomous (a dip - a piece of bread is cut off and dipped in the dish). Also, the Egyptian kitchen is majorly depended on oil more than diary-divided fats. For instance, Falafel or Ta'ameyya is one of the famous and popular Egyptian traditional food which the major of Egyptians daily eat. It is made from beans and cooked by a deep-frying method. ${ }^{20}$

Thus, it has been indicated that according to MD pyramid, there is a probability to nominate MD in Egypt amongst the theme's state parties by the Mediterranean diet foundation and UNESCO ICH list. At the base, nutrients that should continue the diet, and at the higher levels, nutrients to be presented in moderate amounts. Moreover, socio-cultural components, MD characteristics, are represented in the graphic design. So, it is not only about prioritizing some groups of nutrients from others, but also taking into account to the selection way; as well as cooking and consuming them. Additionally, it represents the

\footnotetext{
${ }^{18}$ FAO, FAO and Traditional Knowledge: The Linkages with Sustainability, Food Security and Climate Change Impacts (Rome, Italy: Food and Agriculture Organization of the United Nation (FAO), 2009), 3, 4, accessed November 16, 2017, www.fao.org/docrep/011/i0841e/i0841e00.htm.

${ }^{19}$ Habiba Hassan-Wassef, "Food Habits of the Egyptians: Newly Emerging Trends," La Revue de Santé de La Méditerranée Orientale 10, no. 6 (December 2004): 901 .

${ }^{20}$ Ibid., 902-4.
} 
composition and number of servings of meals. ${ }^{21}$

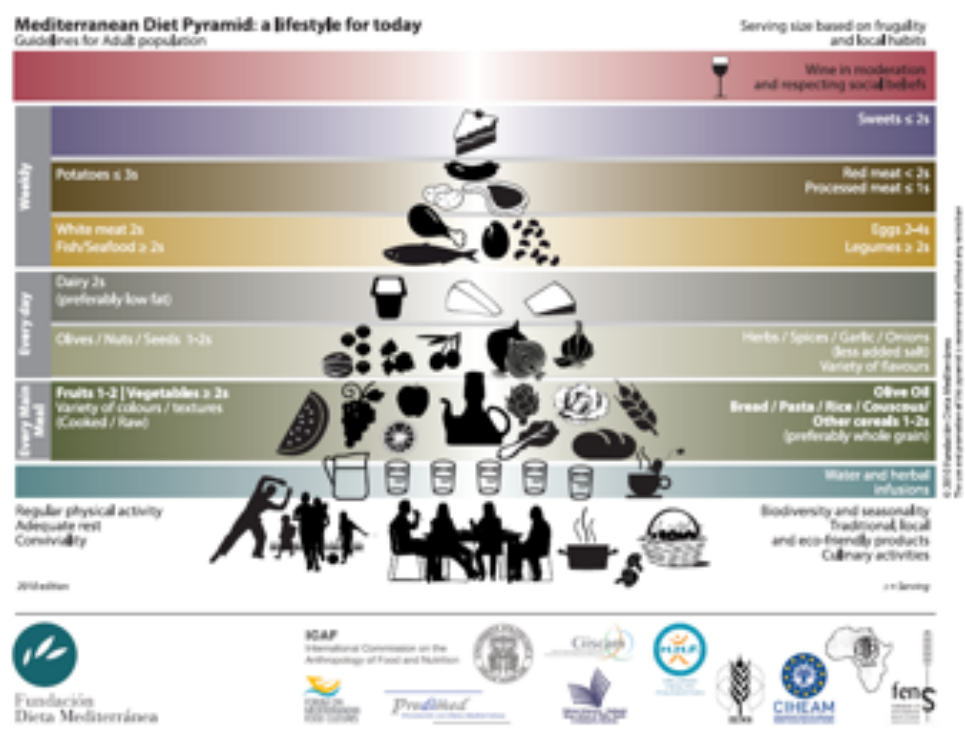

Figure 2: Mediterranean Diet Pyramid

Source: Fundación Dieta Mediterránea. "The Mediterranean Diet Pyramid." The Mediterranean Diet, 2010. Accessed November 19, 2017, http:// mediterradiet.org/dietamed/piramide_INGLES.pdf.

Considering the human-induced impacts, MD and its components face a group of threats such as a globalization, the lack of lifestyle homogenization, awareness, understanding and appreciation. It is traditionally an expression for the intercultural exchange which had been done along the millennia between the local communities and cultures of the Mediterranean Basin overall. Therefore, these threats have high impacts erasing the cultural heritage of the Mediterranean basin and lacking the heritage transmission. ${ }^{22}$

In fact, MD is an example of sustainable lifestyle that to concern the bio-cultural context. According to the 2007 Barcelona Declaration on MD as ICH, "[MD] is continuously recreated in response to the environment in the diverse communities of the area through their respective local shades, which surround them with a feeling of identity". It helps upgrading the sense of conviviality and social peace; and the sense of belonging of such cultural identity. These sense was grown up as a result of consuming the common fresh, and natural products which come from the respective territories enhancing the continuity aspect and respecting the cultural diversity at the same community. ${ }^{23}$ Thus, regarding to this declaration, inscribing MD manifestations in Egypt at UNESCO ICH list will be given full support maintaining and preserving this significant theme as well as its consequent utilities for the Egyptian local community.

Actually, income is a great challenge for sustaining the Mediterranean communities to follow a successful and professional nutritional system or sustainable food options. Estimating the economics of the consumption perspectives in the Mediterranean countries, there are some reports which have been stated the positive impacts of MD on the prices of the traditional products and the cost of the suitable lifestyle; as well as the quality and availability of the Mediterranean food for various socio-economic categories. Moreover, the nutritional system of MD has a great effect to raise the incentives and subside on its sustainability

\footnotetext{
${ }^{21}$ Fundación Dieta Mediterránea, “The Mediterranean Diet Pyramid Has Adapted to the New Way of Life,” The Mediterranean Diet, 2010, accessed November 22, 2017, http://mediterradiet.org/nutrition/mediterranean_diet_pyramid.

${ }^{22}$ Rennaa et al., op. cit., 64; Dernini, op. cit., 289.

${ }^{23}$ Ibid., 289; Petrillo, op. cit.; Scovazzi, op. cit., 106, 107.
} 
pattern.${ }^{24}$ Realizing the former context, in regard of the poverty rates in Egypt,

Egypt is an obvious example of dependence of the poor segments of the population on the subsidized staplefood (bread) resulting in a high energy content made up of empty calories. This level of poverty allows little room for food diversity or for adequate intakes of other essentialnutrients. ${ }^{25}$

If the Egyptian governmental authorities seek, collaborating together, to invest the positive impacts of documenting, managing, promoting, nominating and inscribing the manifestations of MD in Egypt, Egypt obtains a great chance to join in particular UN sustainable development goals. Additionally, in case that has been done, there are a group of positive socio-economic intercultural consequences which will appear according to the following objectives:

1. Curating the heritage characteristics of Egyptian cities and reviving the national cultural identity at each Egyptian city.

2. Decreasing the national debt via operationalizing the national export and import process among MD State Parties, regarding MD ingredients.

3. Upgrading the national income via to save the level of foreign currencies.

4. Activating the national and international "cultural" tourism. In diplomatic collaboration with MD State Parties, Egyptian cultural tourism obtains new distribution channels.

5. Delivering the "cultural" tourism among the whole Egyptian cities.

6. Creating a new type of heritage tourism "Social Exchange Tourism" with MD State Parties. Egypt can deliver its Mediterranean culture with these state parties creating events, festivals, and fairs presenting our MD-divided traditional foods, crafts, and so on.

7. Transforming practically the heritage knowledge from generation to generation via to invest the role of women in Egyptian society.

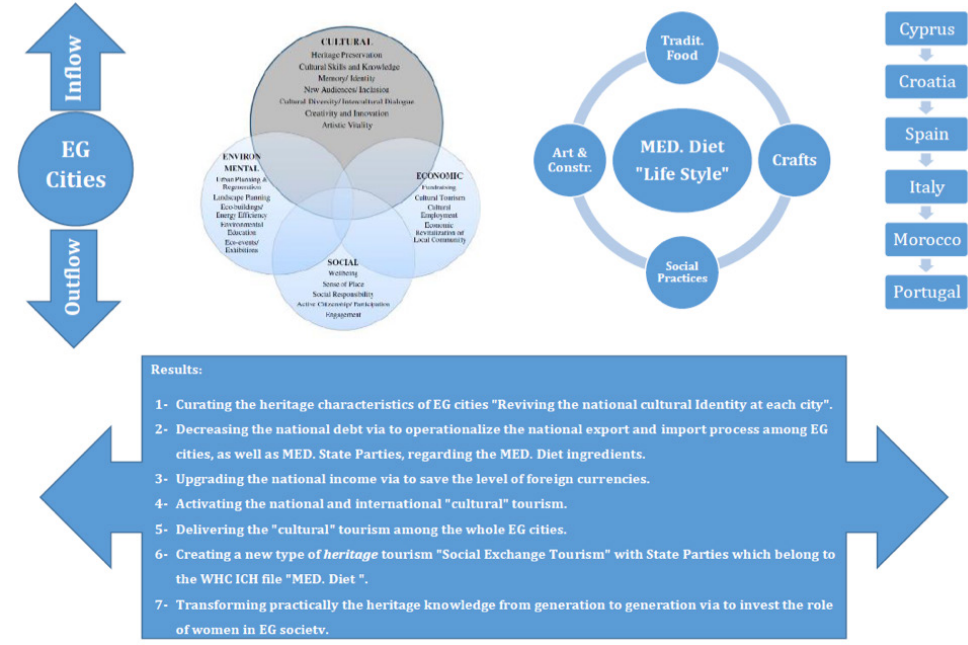

Diagram 3: The Mediterranean Diet as an Intangible Cultural Heritage and Sustainable Development Source: (C) Authors, December 2017

\footnotetext{
${ }^{24}$ Cosimo Lacirignola et al., Mediterranean Food Consumption Patterns: Diet, Environment, Society, Economy and Health, ed. Rekia Belahsen et al. (Rome, Italy: Food and Agriculture Organization of the United Nation (FAO) and International Center for Advanced Mediterranean Agronomic Studies (CIHEAM), 2005), 30, accessed November 19, 2017, www.fao.org/3/a-i4358e.pdf.

${ }^{25}$ Padilla et al., op. cit., 10.
} 
Egypt is considered one of the Mediterranean basin states where to be a diversified cultural area including various traditional local community-derived manifestations. Considering MD theme, Egypt joins the whole Mediterranean states in the same ICH representatives facing a great challenge to preserve and sustain all of these. Providing this right, the researcher presents two Egyptian geographical zones such as Siwa Oasis and Kafr el-Sheikh governorate. These cases were selected as an example for the agricultural and fishing community.

\section{First Case Study: Siwa Oasis - Palm tree-derived Diet "Agricultural Landscape"}

Siwa oasis is a great cultural landscape. It is located at the geographical zone of Marsa Matruh governorate where faces the Mediterranean Sea. The Matruh emblem includes numerous symbols, which represent MD cuisine in Siwa, such as a palm treederived products (the main crop), olive branches (the secondary element), and the meat element. Along the ancient Egyptian civilization era, Siwa was called "Sht Am" which means the land of the palm trees"
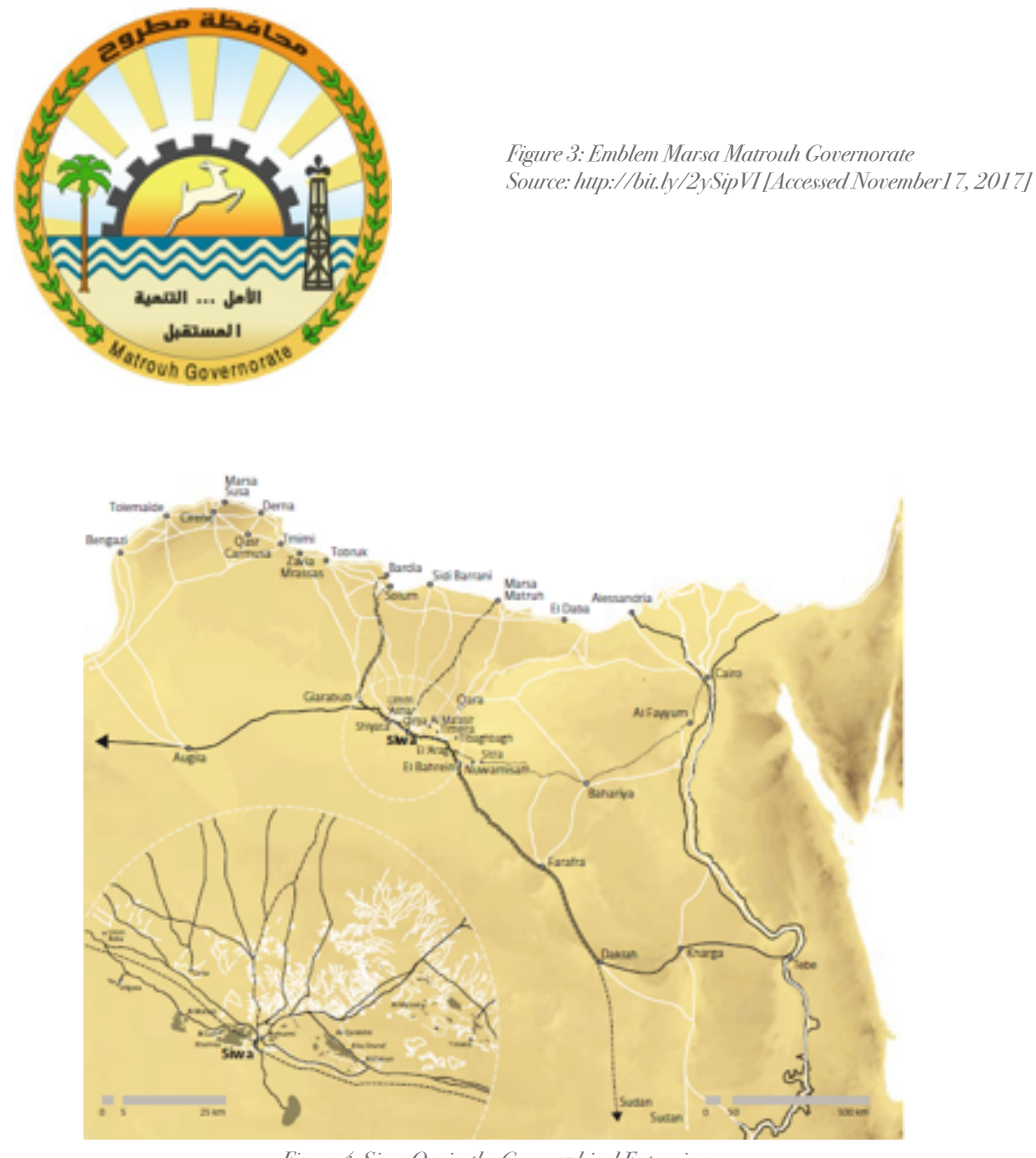

Figure 4: Siwa Oasis, the Geographical Extension

Source: Petruccioli, Attilio, and Calogero Montalbano, eds. Actions for a Sustainable Development: Siwa Oasis. Bari, Italy: Dipartimento di Ingegneria civile e Architettura, 2011, 30

${ }^{26}$ Margaret M. Vale, Siwa: Jewelry, Costume, and Life in an Egyptian Oasis, 1st ed. (Cairo: The American University in Cairo Press, 2015), 210. 
Considering the former context, Siwa includes originally various Barbar-derived ethnical groups due to interacting with the North Africa states such as Libya, Tunisia, and Morocco ${ }^{27}$. Thus, oasis has the diversified ICH representatives including craftsmanship, cuisines, festive events, social practices, language, and built vernacular heritage as well.

As agricultural landscape, there is a group of interaction between the local community and their surrounding context and environment. Siwan traditional cuisine joins MD cuisine including the following components: rice “Bhat”, lentils "Dal”, bread "Rot", pickles "Achar", and vegetables "Sabji".

Regarding the culinary typology of MD, it has been indicated by the researcher the cultural context and preparations for some of Siwan traditional cuisines, for example:

1- Makhmakh - this cuisine was cooked cutting the fresh leaves of the uncultivated grass "Rigl" combining with broth, tomato, lentils, and hot pepper. The final product is thicker than the Egyptian popular dish "Molokhia".

2- Reearin - lentils, molokhia, hot green pepper, olive oil, and bread

3- El Boh Mardam - this cuisine is originally derived from the Libyan cuisines. It was barbecued beneath the fire including the mutton meat and Shali rice.

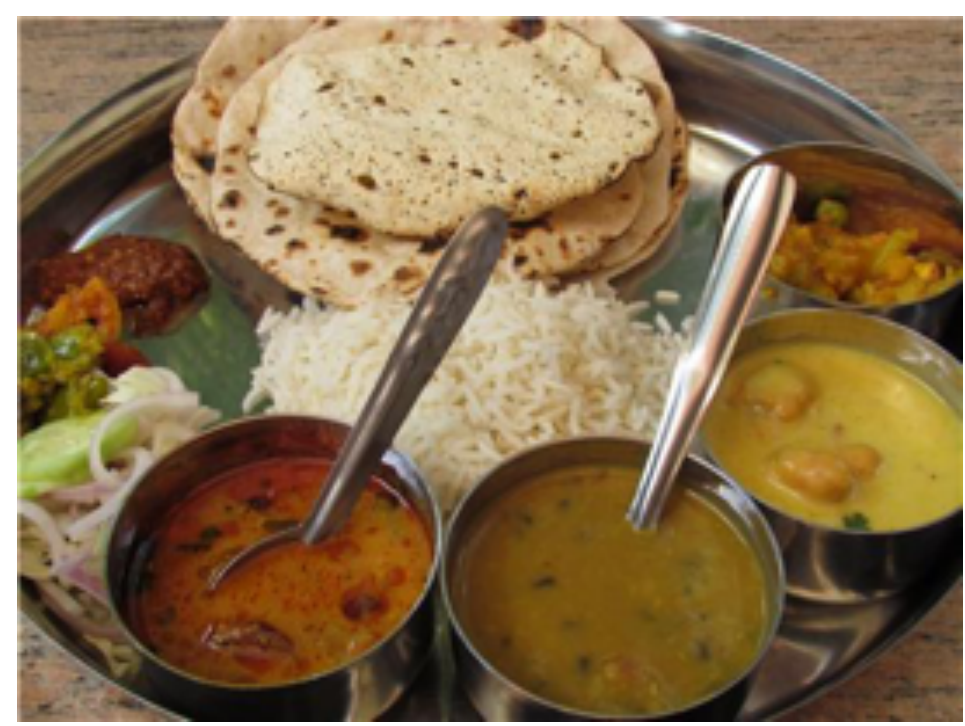

Figure 5: Siwan Traditional Cuisines Source: http://im.hunt.in/cg/Siwan/City-Guide/ thalo.jpg [Accessed November12, 2017]
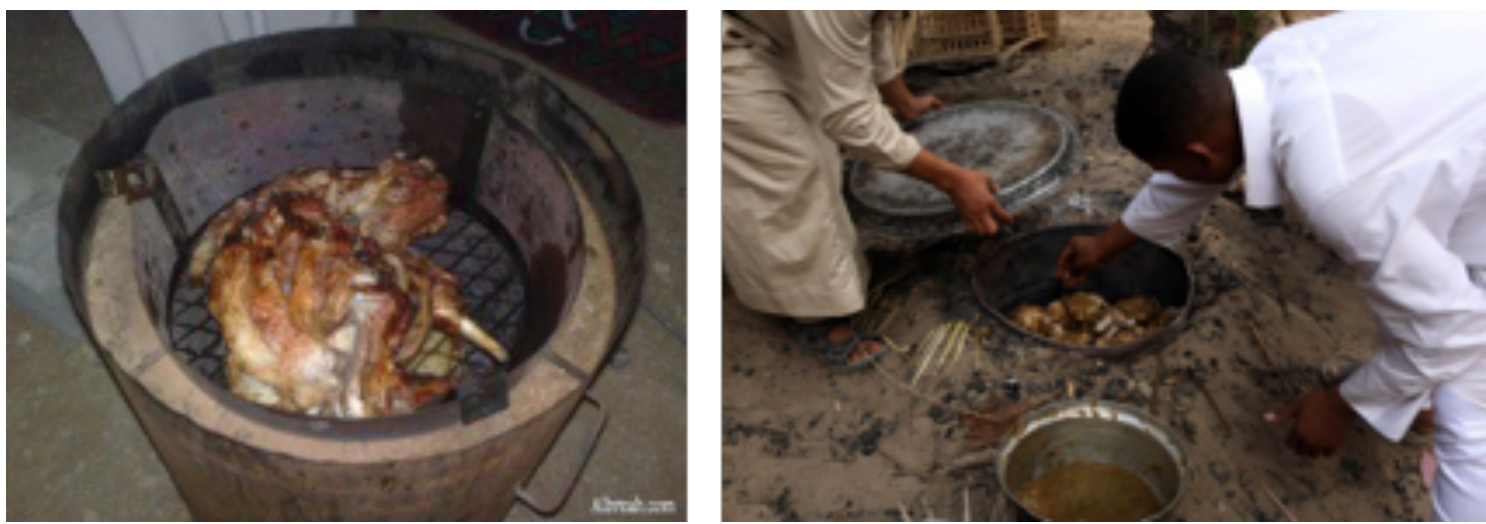

Figure 6: Cooking el Boh Mardam - Shali rice + mutton meat

Source: http://identity-mag.com/wp-content/uploads/2016/02/1-3-300x225.jpg; http://bit.ly/2yTrTnU [Accessed November 12, 2017]

4- Chokha-steamed mashed potatoes, chopped onion, and spices

5- Dhuska - deep fried rice and ghee

6- Edsheesh - a crushed wheat and broth. It is a last day of a wedding party and a bridal shower "Hena"-related cuisine

7- Puja, Pittha, Ghugni, and Pua are various names for the same dish which was prepared for the celebration ceremony

${ }^{27} \mathrm{FAO}, 10$. 
consisting of these same ingredients: powdered rice, sugar, milk, honey, and ghee.

8- Choora - beaten rice and sugar "Jiggery"

9- Malpua and Makhana are prepared consisting of sugar and milk and delivered as a kind of charity "Kheer".

10- Engeel Pita - it is a wedding rituals-related cuisine. It consists of mashing dates mixing with flour and liquid.

11- Tagellan Inteni - ground dates and wheat flour.

12- Other palm trees-derived drinks such as "Latby" - palm juice, and dates seeds coffee. ${ }^{28}$

Although Siwa has all of these cultural cuisines, there are some food brands, e.g. Nestle Cerelac (Wheat and Dates) and BascoMisr (Bisco Datto), which invest this cultural significance without refereeing to the cultural background and not to contribute raising an awareness the Egyptian local community for their cultural heritage as well. Therefore, it has been observed by the researcher that these actions

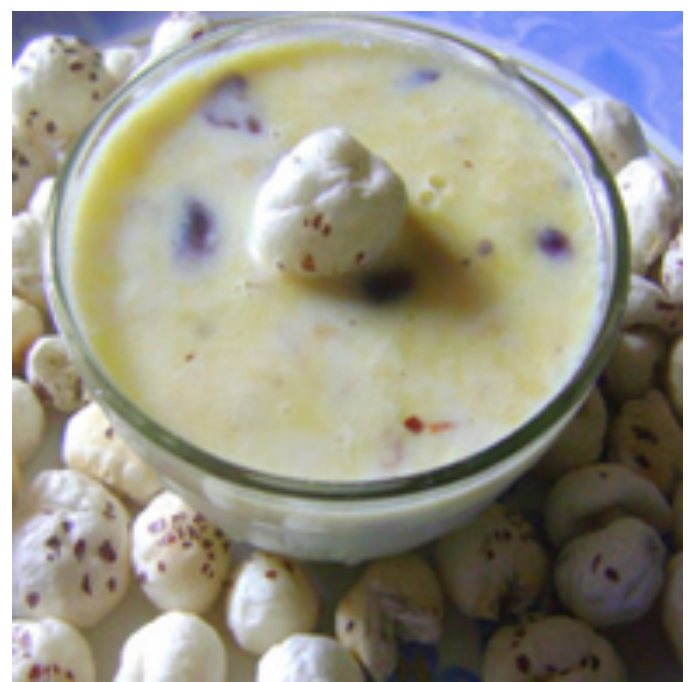

Figure 7: Makhana - Dessert during ceremonies "Puja" Source: http://im.hunt.in/cg/Siwan/City-Guide/kheer.jpg [Accessed November 12, 2017] might indirectly and gradually contribute disappearing the features of the Egyptian cultural identity and breaking down the factor of "authenticity and integrity". So, it has been recommended by the researcher that the Egyptian authority has to develop the national regulations saving the local cultural copyrights and supposing a special article for the private companies, which invest the manifestations of Egyptian ICH, raising the local awareness in the framework of their marketing campaigns.
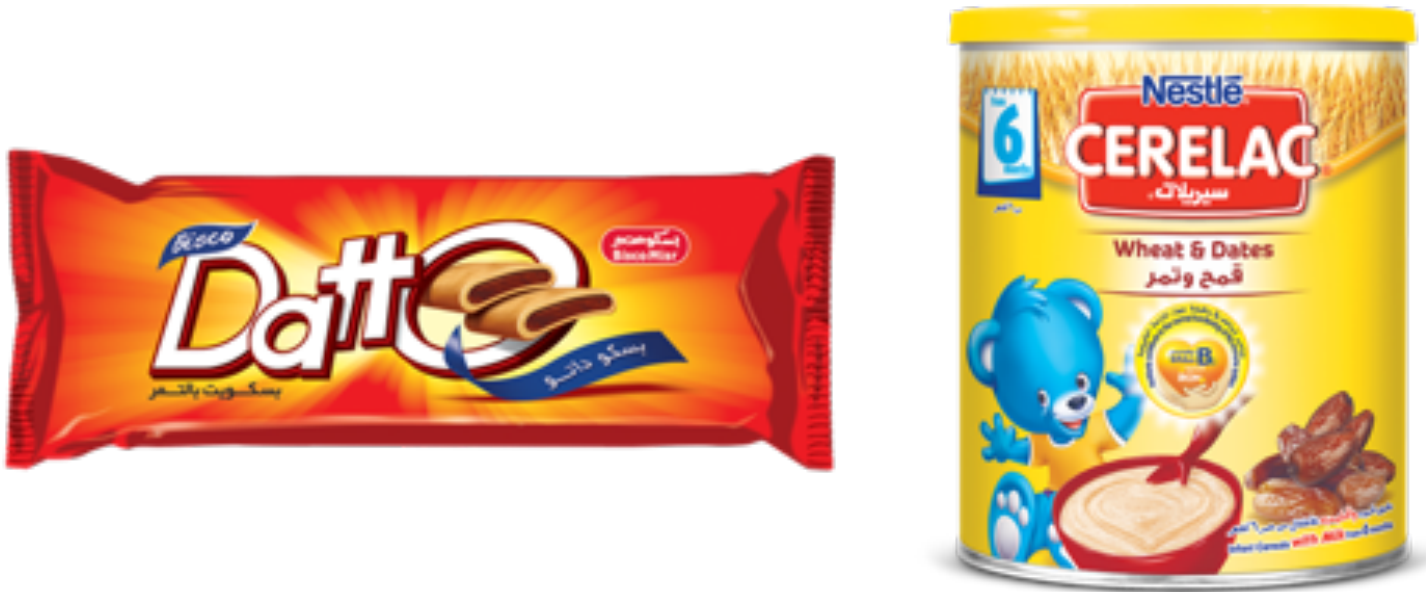

Figure 9: Tagellan Inteni between Integrity and Modernity

Source: www.biscomisr.com/images/Products/Datto\%20Big.png; www.cerelacarabia.com/sites/ default/files/4-PP-WheatDates.png [Accessed November 13, 2017]

\footnotetext{
${ }^{28}$ The names of these cuisines is derived from Amazigh language; unfortunately, these drinks are gradually vanishing. Culture, "Siwa Culture," Culture, 2017, accessed October 10, 2017, www.siwaoasis.com/siwa_food.html.
} 
Siwa has various the palm tree-derived practices either modern, e.g. packaging, or traditional crafts such as the dates seedsmade curtains, leaf midribs-made chair, fibrous sheaths of petiole base -produced rope, the baskets - which was used to carry vegetables and other general items-, mats, and brooms. Siwan artists affected and interacted with their surrounding nature investing the element of a palm tree in their traditional artificial products, e.g. the jewelry and ornaments, and the embroidery of Siwan customs and female clothes. Appreciating those artists, FAO (2016) has been honored mentioning Siwan artist Mr. Yussef Ibrahim who painted his pallet expressing the traditional harvest and drying the dates in Siwa ${ }^{29}$. Furthermore, Siwan built vernacular heritage depends mainly on the palm trunks as the floor beams and also, invests the palm fronds as a fence.
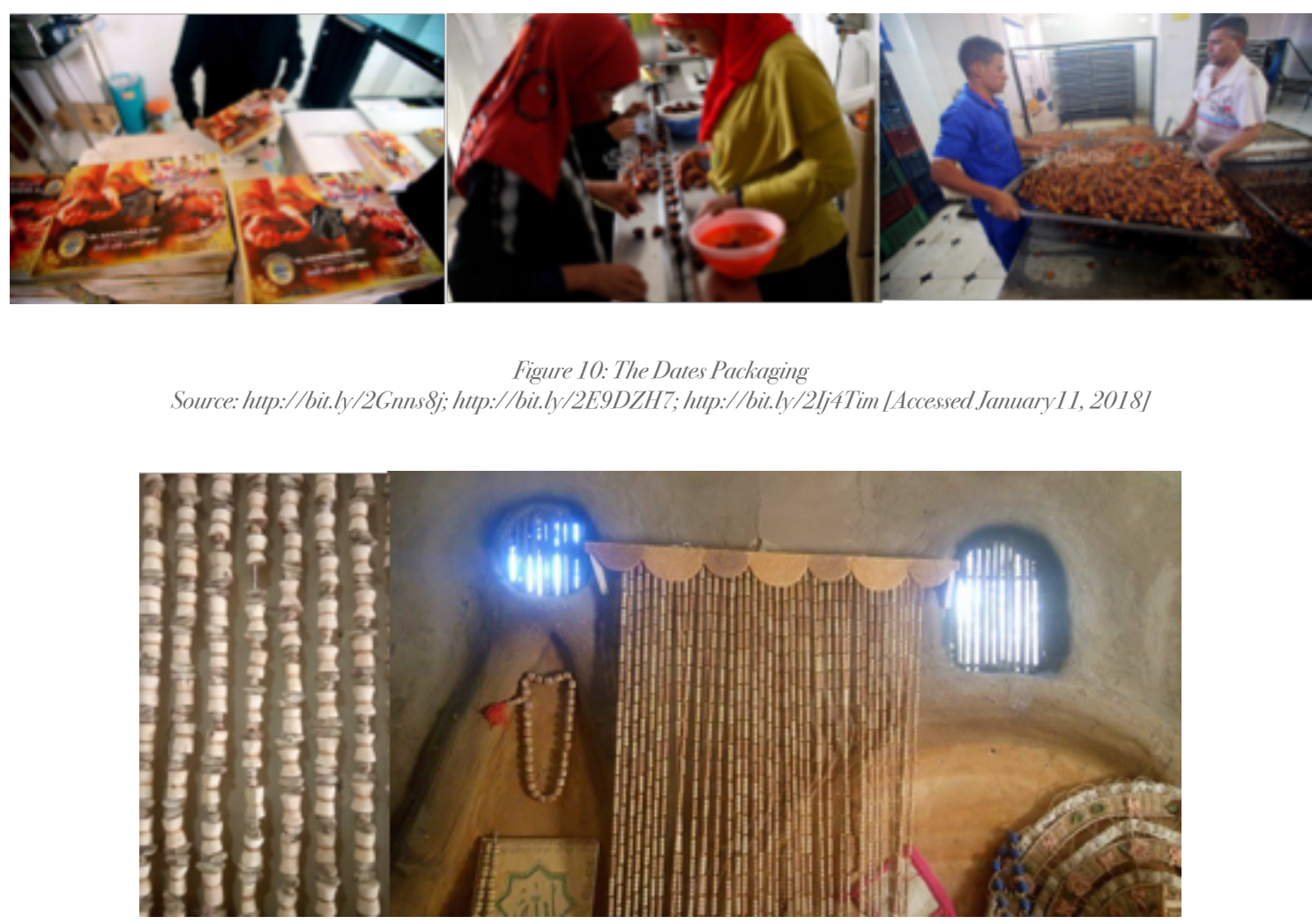

Figure 11: The Dates Seeds-made Curtains

Source: (CUsama Ghazali http://bit.ly/2zkOEQd; http://bit.ly/2zj8FEW [Accessed November 6, 2017$]$

${ }^{29}$ FAO, Proposal for Designation as Globally Important Agricultural Heritage Site: Siwa Oasis, Egypt. 


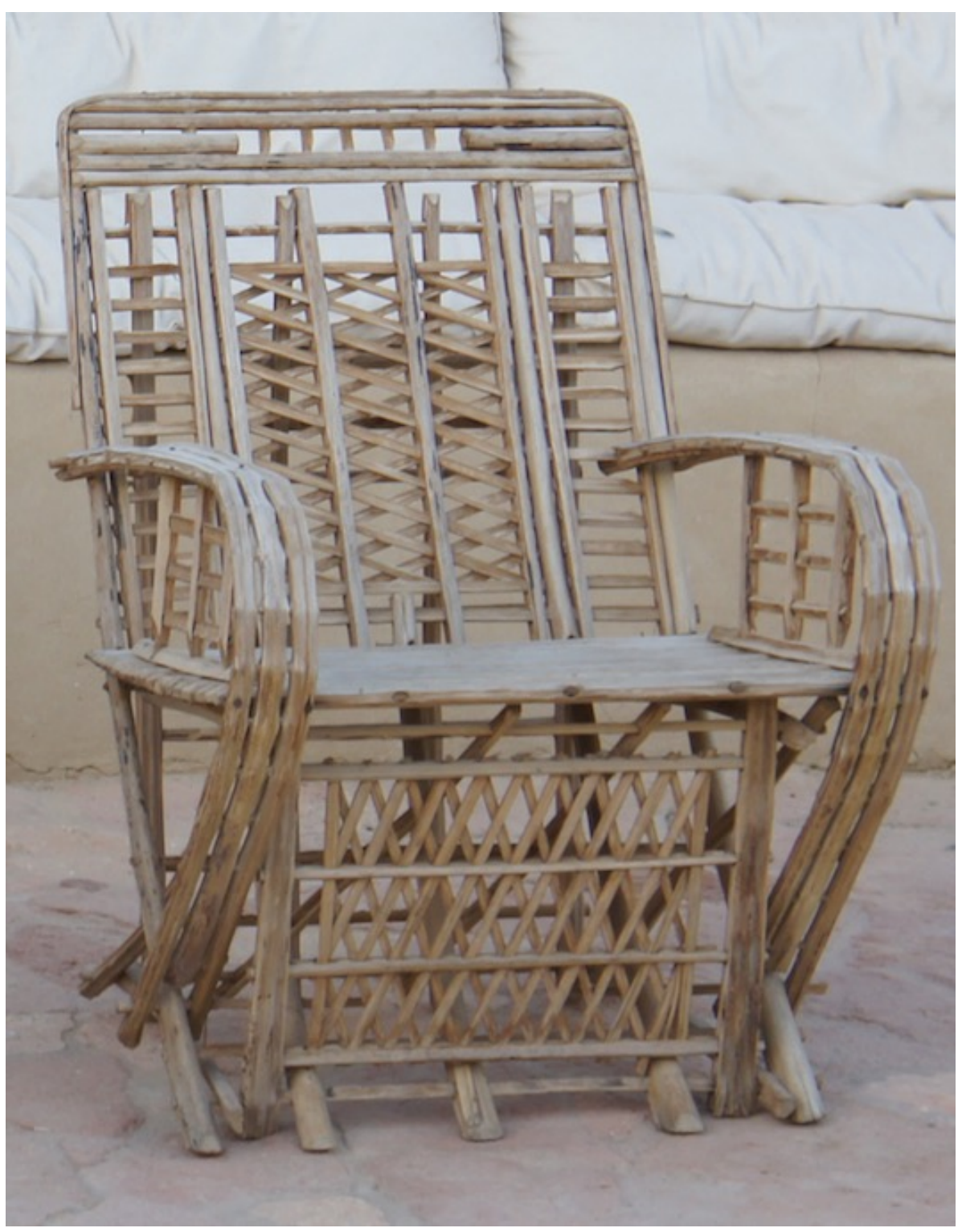

Figure 12: Leaf Midribs-made Chair

Source: (OHermann (FAO, 2016. Accessed October 15, 2017, www.fao.org/3/a-bp825e.pdf.) 


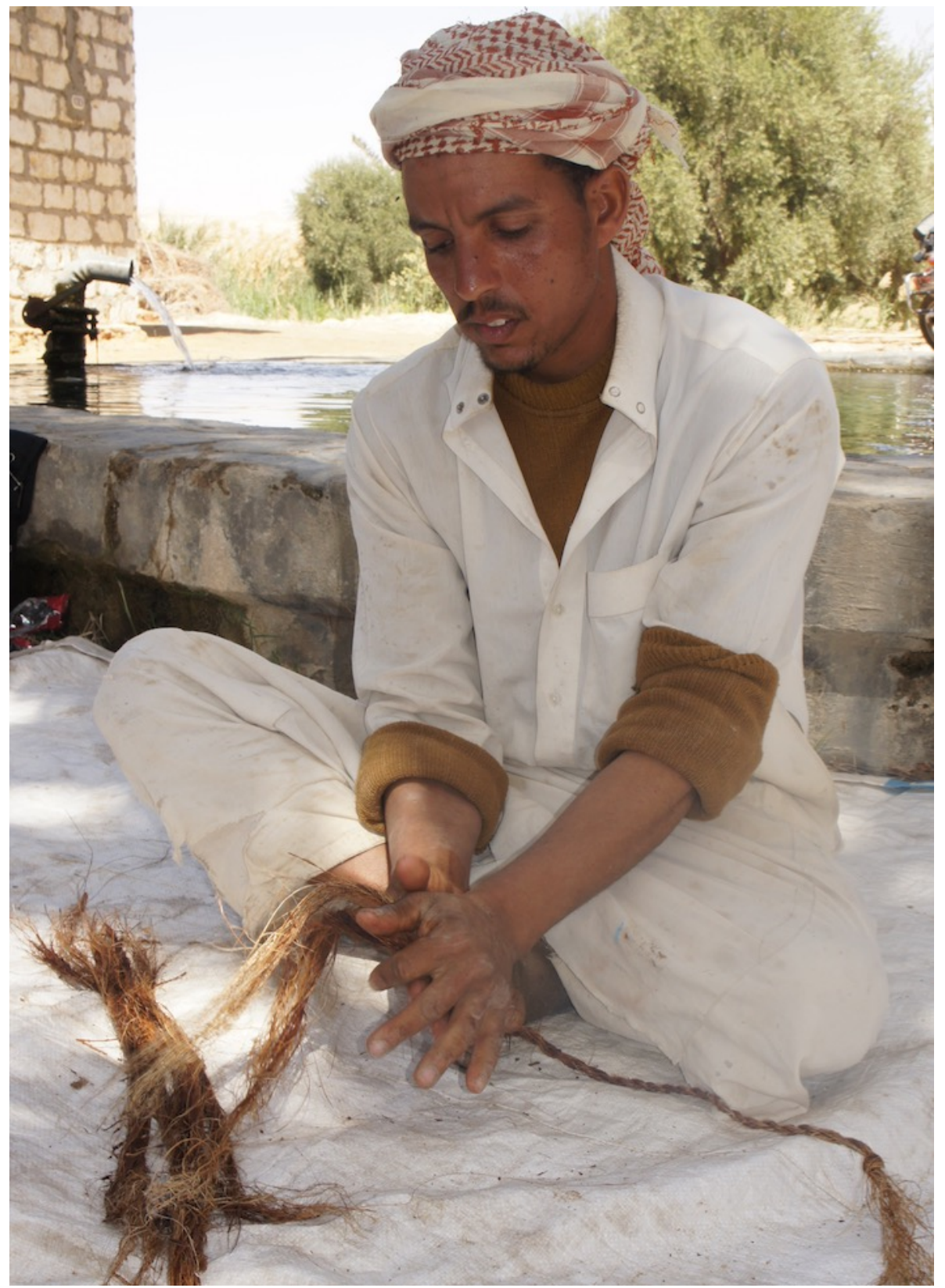

Figure 13: Fibrous Sheaths of Petiole Base-produced Rope

Source: (CHermann (FAO, 2016. Accessed October 15, 2017, www.fao.org/3/a-bp825e.pdf.) 


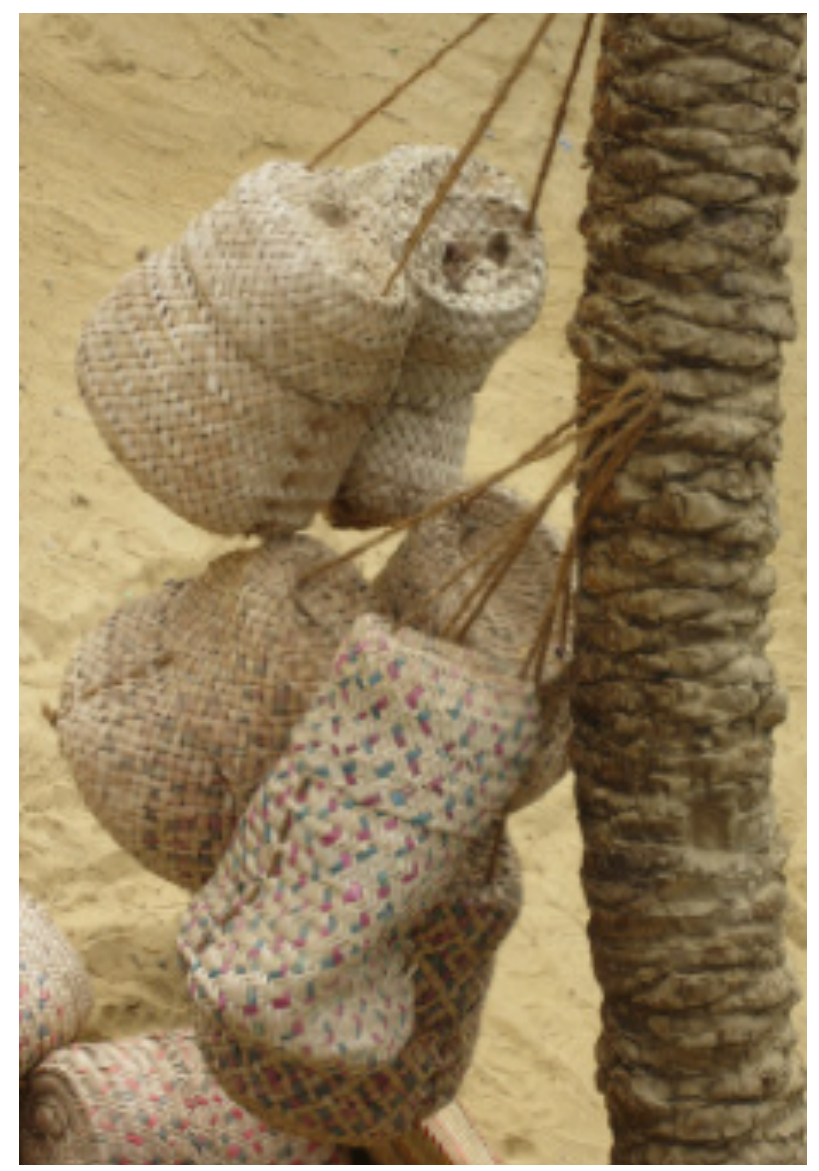

Figure 14: Baskets Woven from Palm, used to carry vegetables and other general items. - Siwa Source: http://bit.ly/2izErpn [Accessed November 9, 2017]
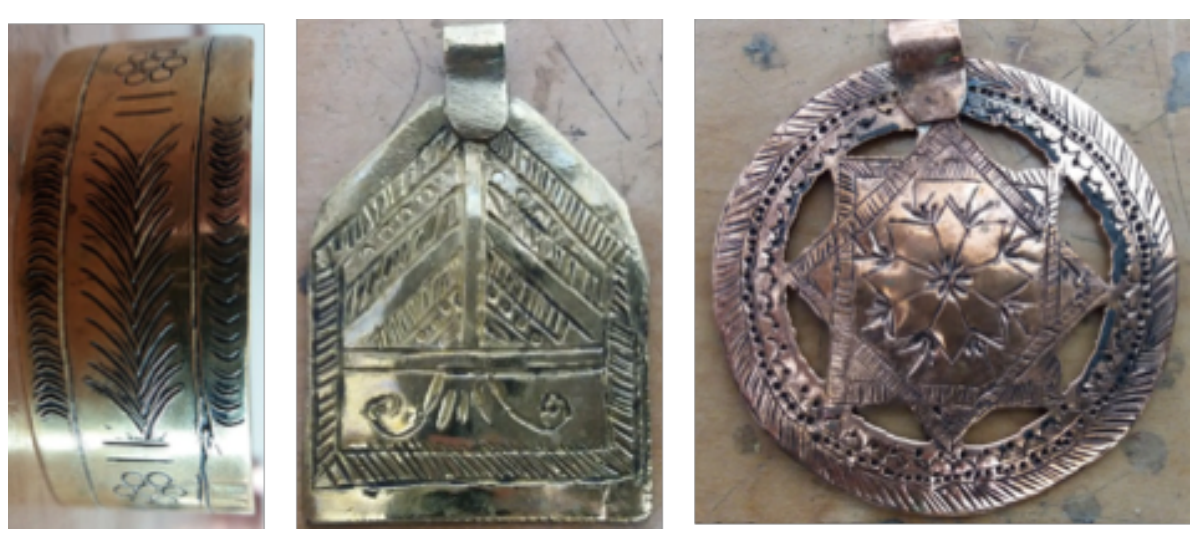

Figure 15: Reflection of Palm Trees on the decoration of Ornament (Pendant-Bracelet), Tradition Crafts Center-Siwa Oasis Photos: CMohamed Badry, Febraury 2017 


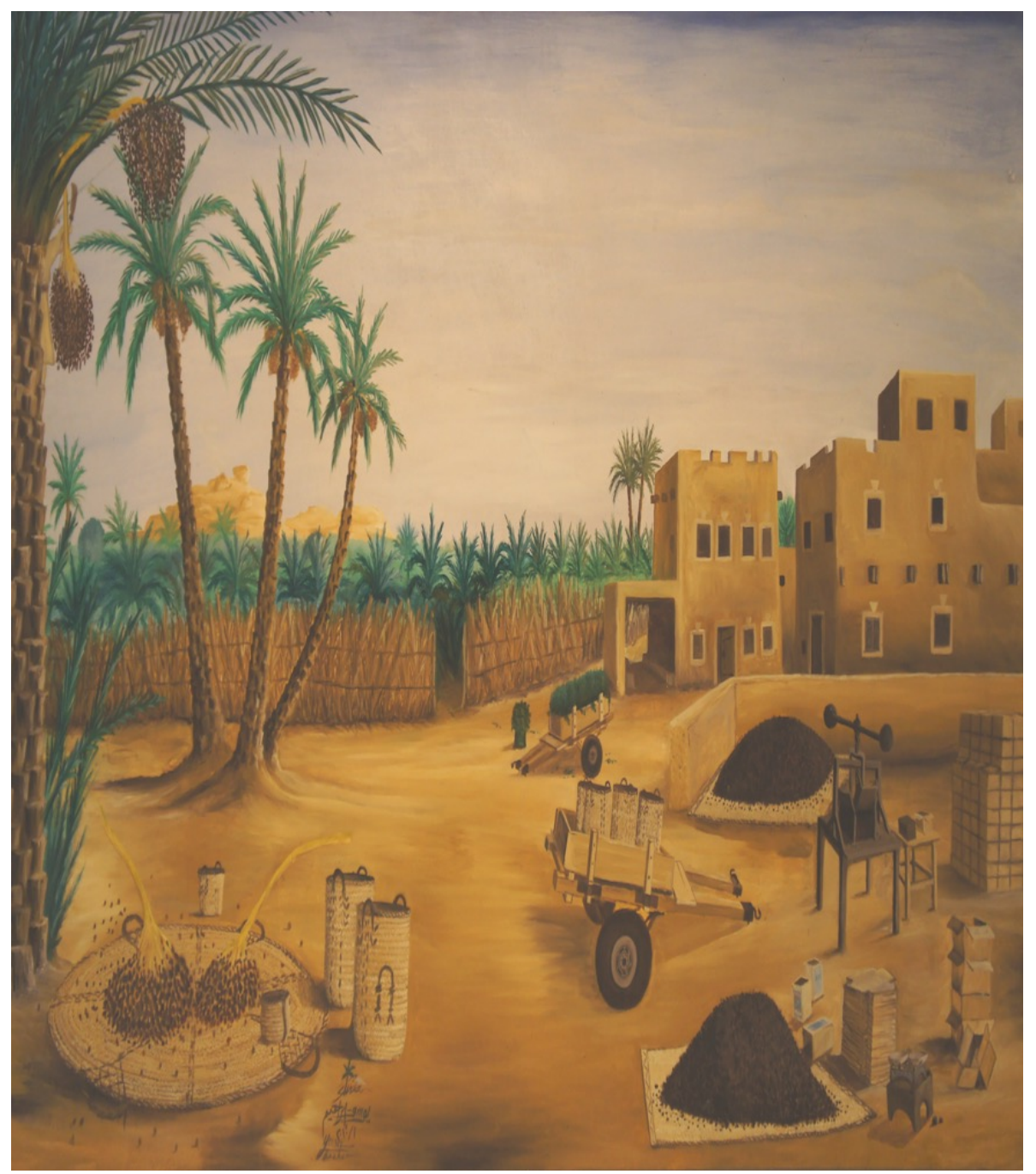

Figure 16: Traditional Drying and Processing of Harvested Dates in Siwa Oasis - Painted by Siwan Artist Yussef Ibrahim Source: FAO, 2016. Accessed October 15, 2017, www.fao.org/3/a-bp825e.pdf.)
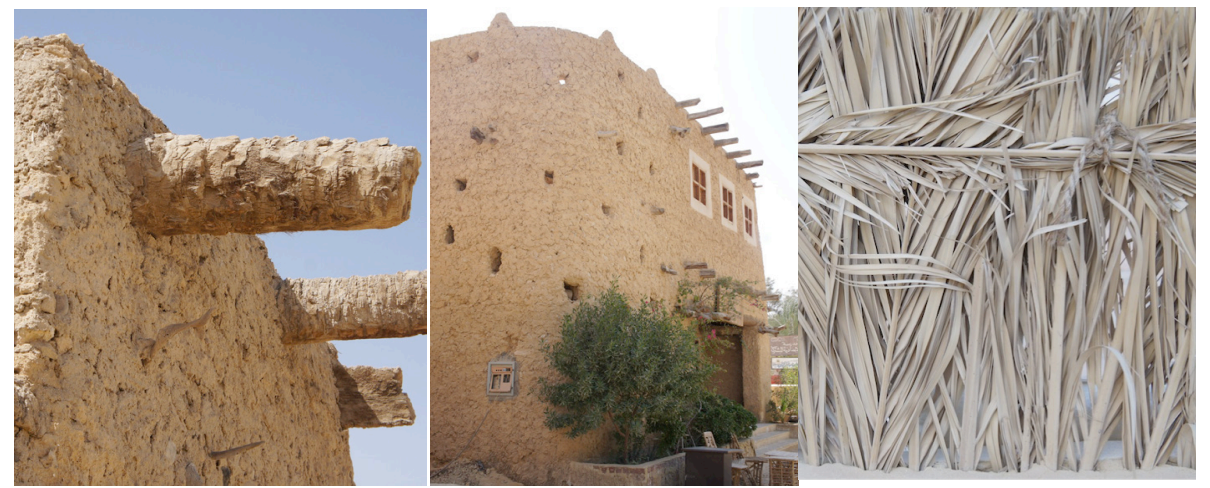

Figure 17: Use of date palm trunks as floor beams; Modern karshif building (Siwa Documentation Center of Cultural Heritage and Natural (; Fence made of date palm fronds.

Source: (CHermann (FAO, 2016. Accessed October 15, 2017, www.fao.org/3/a-bp825e.pdf.) 
Siwa has also a group of MD-related social practices such as rituals, festive events, and dancing. For instance, the annual date palm festival was started in 2015 enhancing the date production sector and marketing the products of the small entrepreneurs. It was supported by the Arabian Caliph award. It was included a number of traditional activities such as to create a fair for the date-derived products, to show a traditional folklore, and to create a heritage education class targeting the Siwan children. ${ }^{30}$
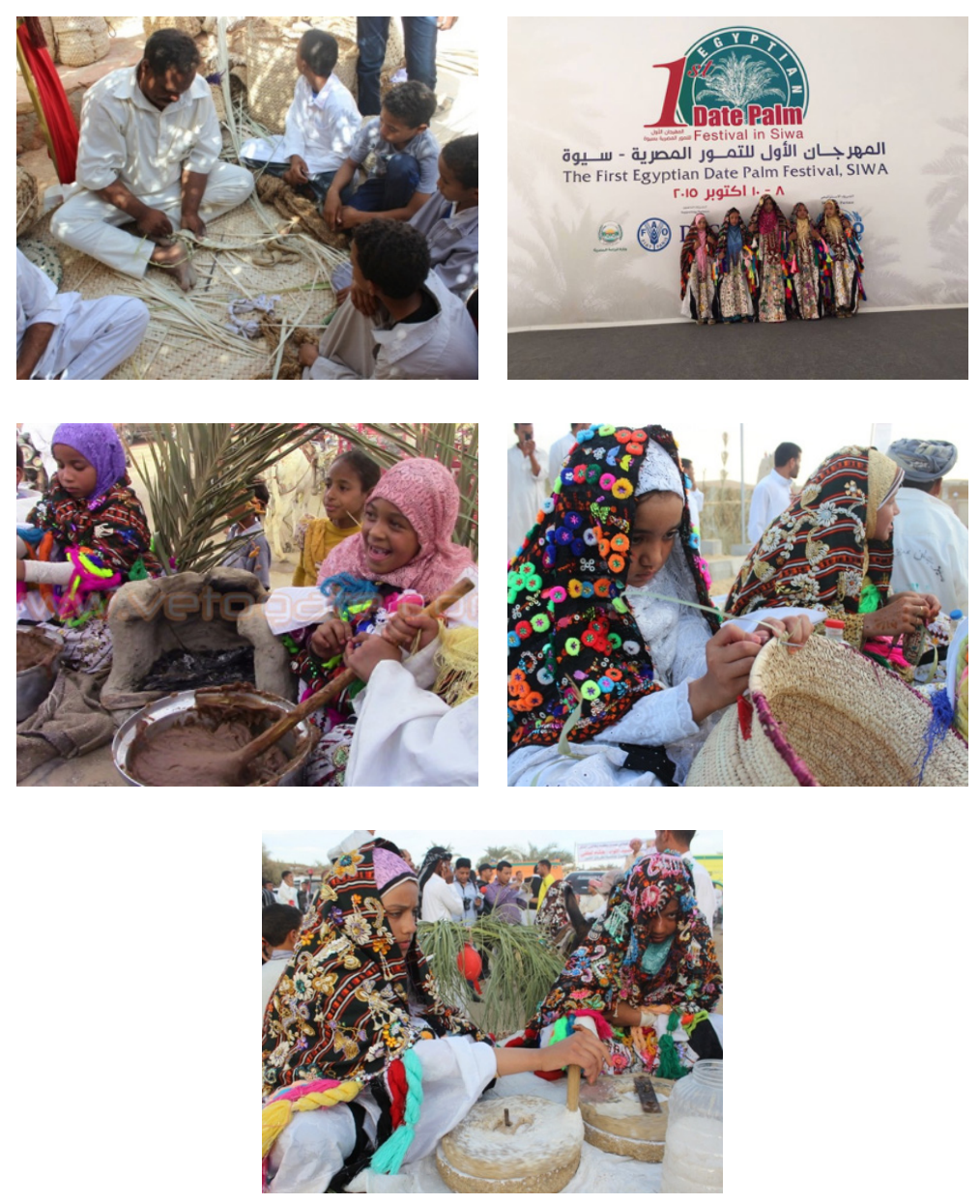

Figure 18: Siwa Date Festival 2015

Source: http://bit.ly/2zQNVHN; www.skyscrapercity.com/showthread.php?p=128090604 [Accessed November 12, 2017]

In addition, Siwa has its main traditional festival Elsaha Festival, Peace Festival, Union Festival, or Harvest Festival. It was started about 160 years ago. In October or November, it held annually and continued along the three moon nights according to Arabian calendar at Dakrour Mountain. Men, children and the young girls attend this festival gathering, cooking Fata cuisine ${ }^{31}$ on the palm tree-fired wood, singing and dancing. ${ }^{32}$

\footnotetext{
${ }^{30}$ Emirates National Media Council, Khalifa International Award for Date Palm and Agricultural Innovation, 7th ed. (Abu Dhabi, United Arab Emirates: Emirates National Media Council, 2015), 32, 45, accessed January 01, 2018, www.kiaai.ae/pdf/2016.pdf.

${ }^{31}$ Fata cuisine is an Egyptian traditional dish which consists of bread, meat, and rice.

${ }^{32}$ Mustafa Gad, "Folklor Wahat Siwa», Majalet al Thaqafa al Shaabiyya, 2012, 4952-.
} 

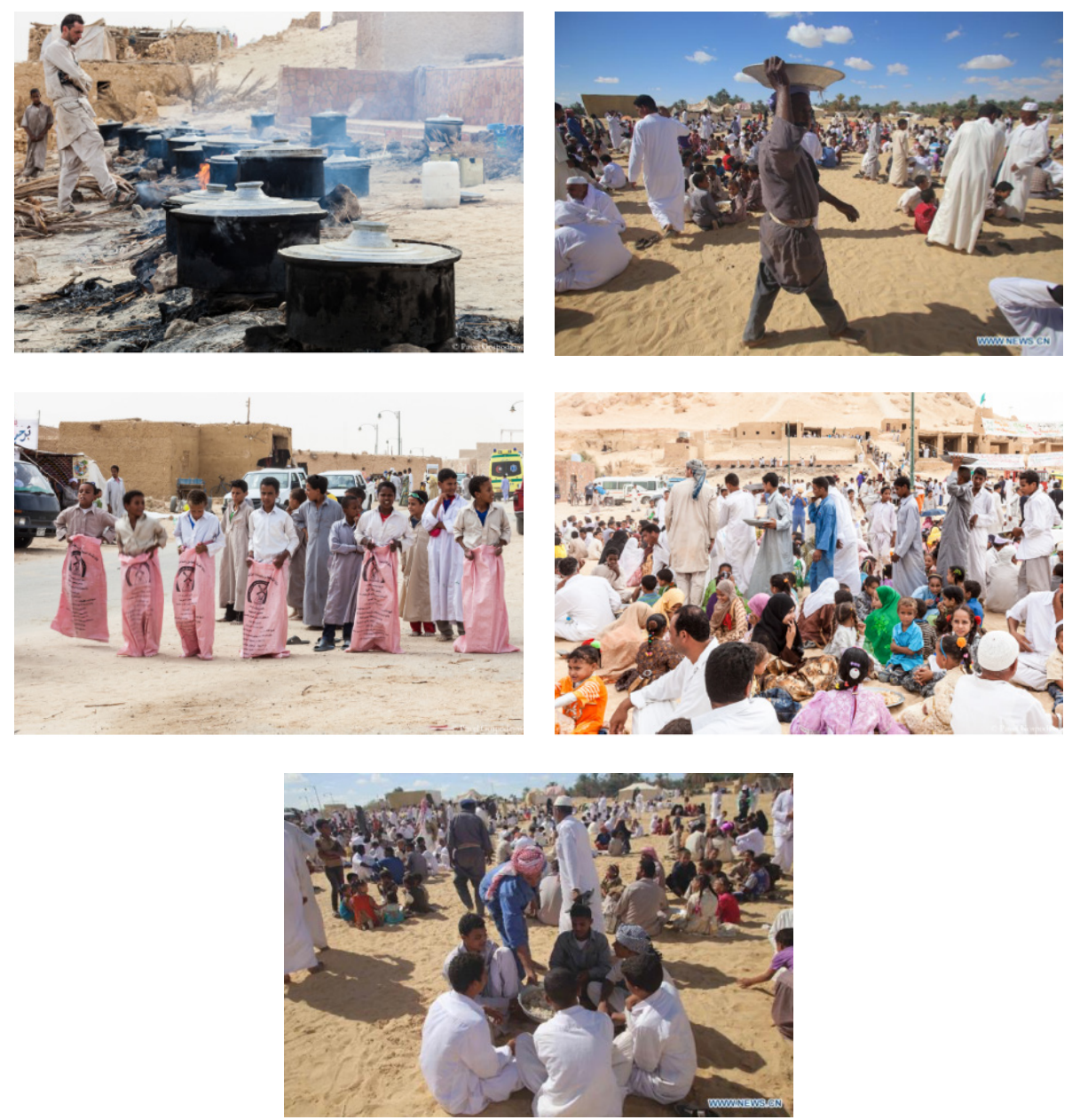

Figure 19: Harvest Festival

Source: www.pavelgospodinov.com/the-siwa-festival-in-egypt/ [Accessed November 06, 2017]

The festival rituals was traditionally starting with collecting the dried bread "Megardal' from the whole Siwan houses regardless the social class. Then, the wealthy people collect a symbolic fee from the whole residents in oasis buying the sacrifices and the cooking supplies. Along the three days, men cook preparing the traditional dish for all residents breaking down the quarrels among the Siwan social classes. Then, they pray together thanks Allah and then, create a Sofian round "Zekr". ${ }^{33}$

${ }^{33}$ Hossam Mehassib, «Raqsat al zagala», Majalet al Thaqafa al Shaabiyya, 2011, 148149 - 

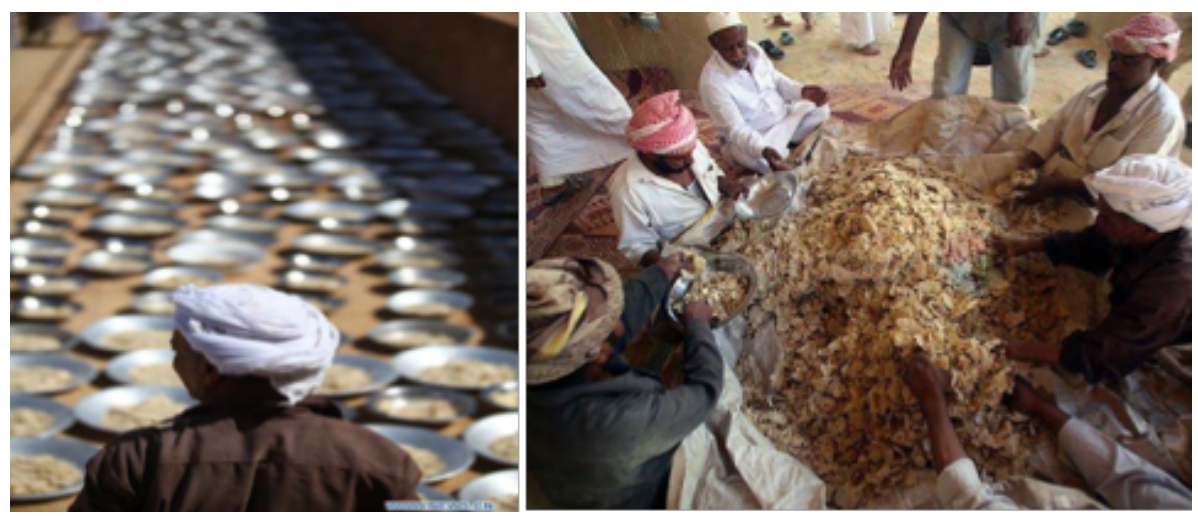

Figure 20: Collecting the Dried Bread "Megardal" from the Whole Siwan Houses

Source:www.masrawy.com/CrossMedia/Siwa/assets/images/1/1.jpg; www.masrawy.com/CrossMedia/Siwa/assets/images/1/2.jpg [Accessed_January $01,2018]$

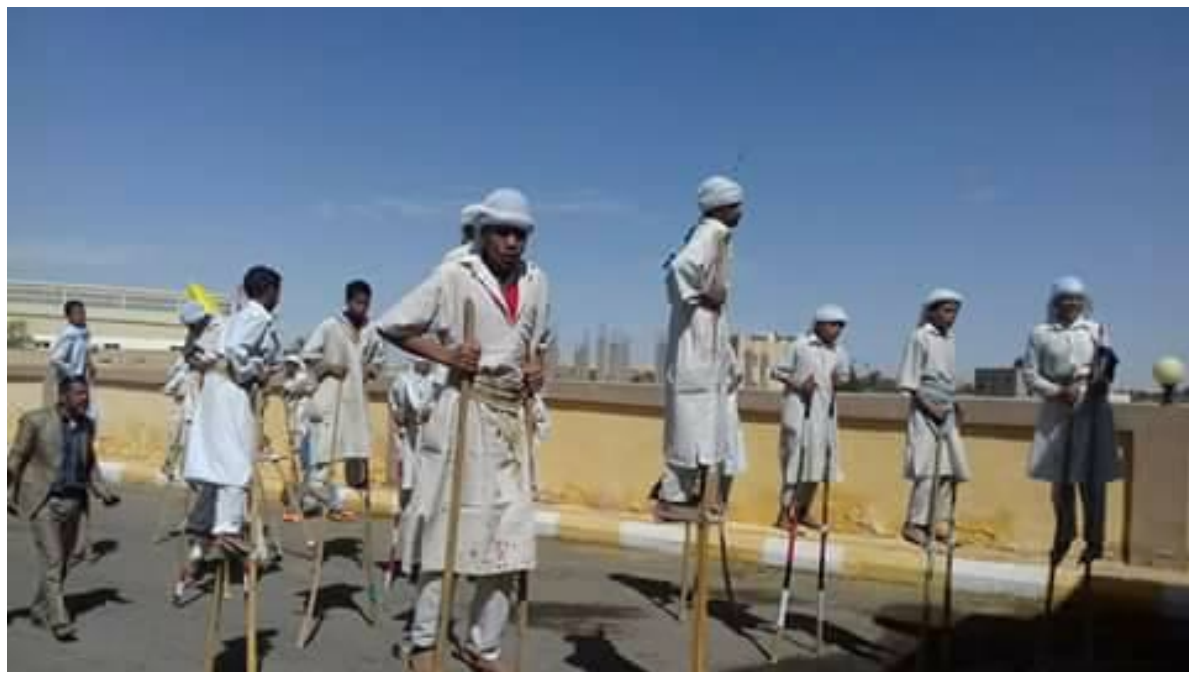

Figure 21: Siwan Traditional Dance "Tajo Tajo"

Source: www.albawabhnews.com/2478159 [Accessed April 30, 2017$]$

Furthermore, Siwan people created a special traditional dance "Tajo Tajo" by the male teenagers welcoming and appreciating the visitors and guests. They have made the palm tree-made long sticks and stopped on it dancing. ${ }^{34}$

\footnotetext{
${ }^{34}$ BawabaNews, "Siwan Traditional Dance “Tajo Tajo,” Al Bawaba Video (https://youtu.be/xQeg3WO4fKo, 2017), accessed April 30, 2017,
} https://youtu.be/xQeg3W04fKo. 


\section{Second Case Study: Kafr el-Sheikh Governorate - Fish-derived Diet "Fishing Landscape"}

Presenting other model of MD in Egypt, it has been referred by the researcher to a fishing-depended community in Kafr el-Sheikh governorate. This governorate is located at the north of delta and faces the Mediterranean Sea. Its emblem consists of two of MD symbols such as the branch of rice plant - the main crop and dish - and the fishing tool "boat" - the main craft at the whole governorate. It includes a number of rural and urban countries where people are mainly working by the fishing or the fishing-related crafts.

For the traditional cuisines, the culinary typology of rice in the urban communityiscalled "Saiadia" 35 whileitiscalled "Madfos" or "Moa'mar"36 in the rural community. The dishes are traditionally depending on the main following components: rice, fish, vegetables, and spices.

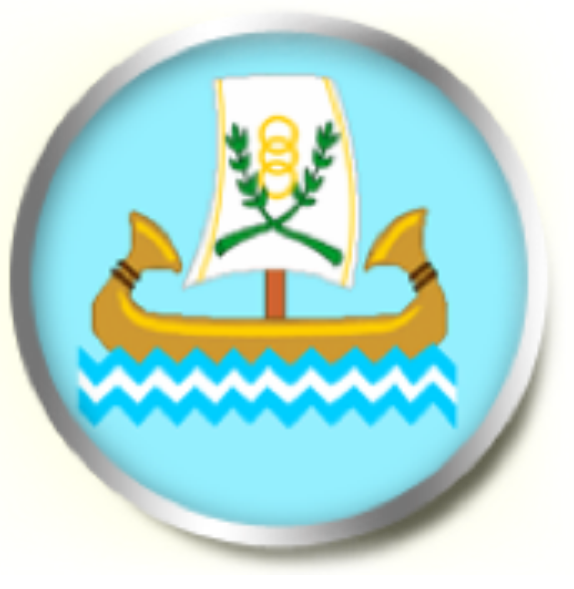

Figure 22: Emblem Kafrel-Sheikh Governorate Source: https://upload.3dlat.com/ uploads/13788266361.png [Accessed November 12, 20171
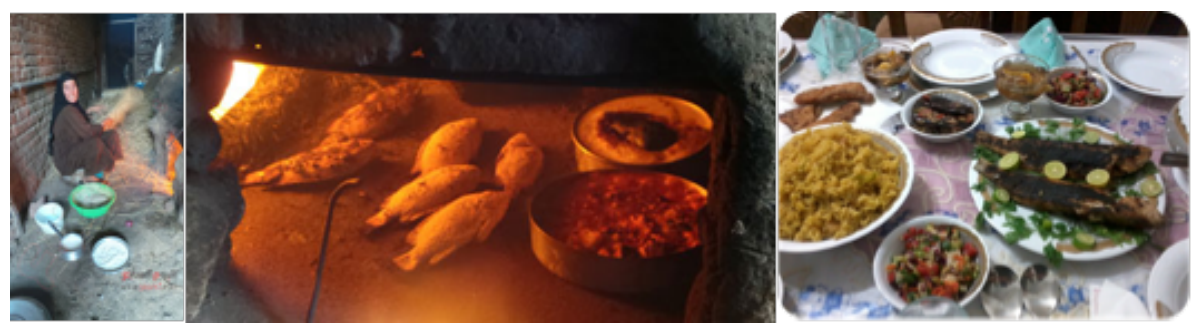

Figure 23: Traditional Cuisine in Kafr el Sheikh's Rural Communities; Traditional Cuisine in Kafr el Sheikh's Urban Cities Source:www.kafrelsheikh.gov.eg/tourism/FolkCuisine_files/image004.png; http://bit.ly/2hmeE3K; http://img:youm 7.com/large/s720142044852.jpg [Accessed November 12, 2017$]$

Kafr el-Sheikh is one of the important countries which have the fish farms in Egypt to cover the local supply from the following types: Tilapia, Mullet, African Catfish, and Carp ${ }^{37}$. These farms are located in Elriyad, Balteem, Qelin, and Elhamool. Also, there are various representations for the salted fish according to the type of fish such as "Renga", "Sardeen" and "Fesekh".

\footnotetext{
35 Saiadia is rice and onion. It is cooked on oven. It is presented with the grilled fish.-

${ }^{36}$ Madfos is rice, milk and meat either beef or chicken. Moa'mar is rice and milk. It is presented with the grilled fish. These cuisines are cooked in a mud traditional oven which is fired by wood and the dried grasses.

${ }^{37}$ Paula Kantor et al., Informal Fish Retailing in Rural Egypt: Opportunities to Enhance Income and Work Conditions for Women and Men (Penang, Malaysia: World Fish, 2014), 7, accessed November 11, 2017, http://pubs.iclarm.net/resource_centre/2014-51.pdf.
} 


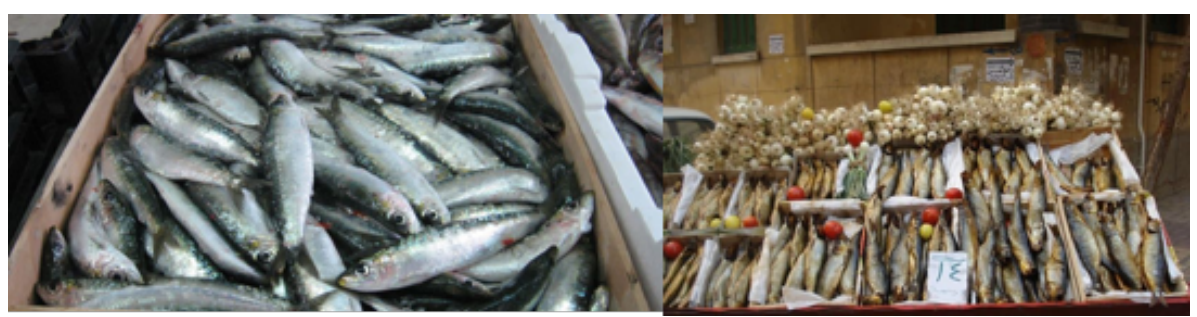

Figure 24: Salted Fish - Renga and Sardeen

Source: http://bit.ly/2zySG8u; http://bit.ly/2yUyz56 [Accessed November 12, 2017]

Fesekh is the salted-fermented Bouri fish (Mugil Cephalus). It is considered one of Egyptian popular dishes since the beginning of the ancient Egyptian civilization especially during the local feasts. It is presented as an appetizer in Kafr el-Sheikh. ${ }^{38}$ Dsouk, Metoubas and Sidi Salem are the most common cities where produce Fesekh according to the ancient Egyptian methodology of salting and storage.

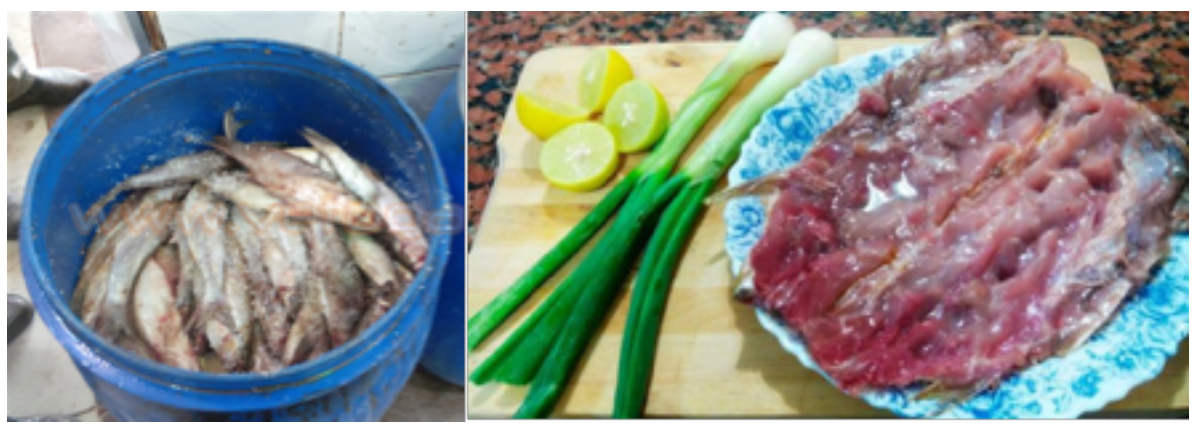

Figure 25: Salted Fish - Fesekh

Source: www.vetogate.com/upload/photo/gallery/111/7/482.jpg; http://bit.ly/2hof7md [Accessed November 12, 2017]

The craft of fishing mainly depends on the aspect of teamwork. In addition, women and men work together in the fish retail market $^{39}$. Fishermen work together in groups. Also, this craft is represented in two forms directly, in a traditional form, interacting with the surrounding nature especially the sea landscape and indirectly, through working at the fish farms, markets, and the fish industries-related factories. It has been estimated that the socio-economic practices occur throughout the commercial interactions between the retailers and the customers "the local community".

\footnotetext{
${ }^{38}$ Laila A. El-Sebaiy and Samir M. Metwalli, "Changes in Some Chemical Characteristics and Lipid Composition of Salted Fermented Bouri Fish Muscle (Mugil Cephalus),” Food Chemistry 31, no. 1 (1989): 45.

${ }^{39}$ Kantor et al., op. cit., 29.
} 

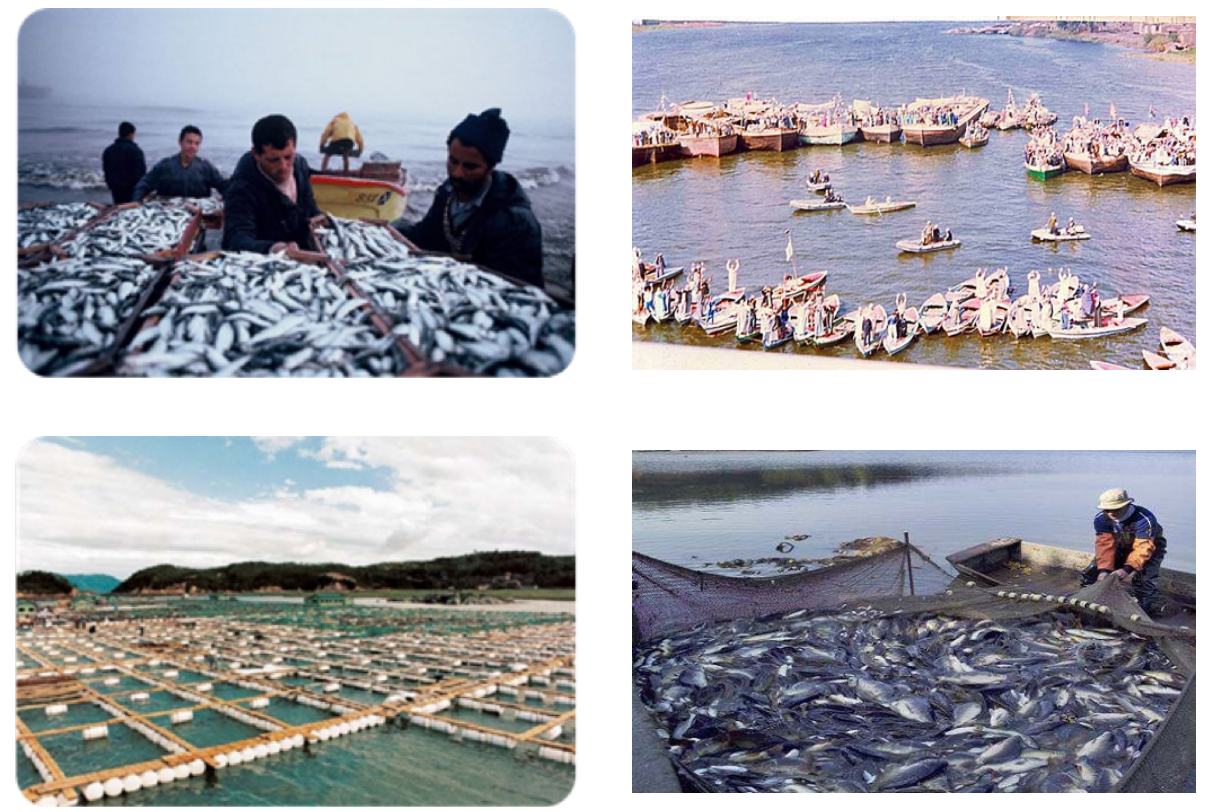

Figure 26: Fishing as a Traditional Craft

Source: http://bit.ly/2ySunCF; www.al3asma.com/upload/471a5eb7d6-img.png; www.al3asma.com/upload/471a5eb7d6-img.png; www.kafrelsheikh. gov.eg/invest/impoSector/clip_image032.png_Accessed November 12, 2017]
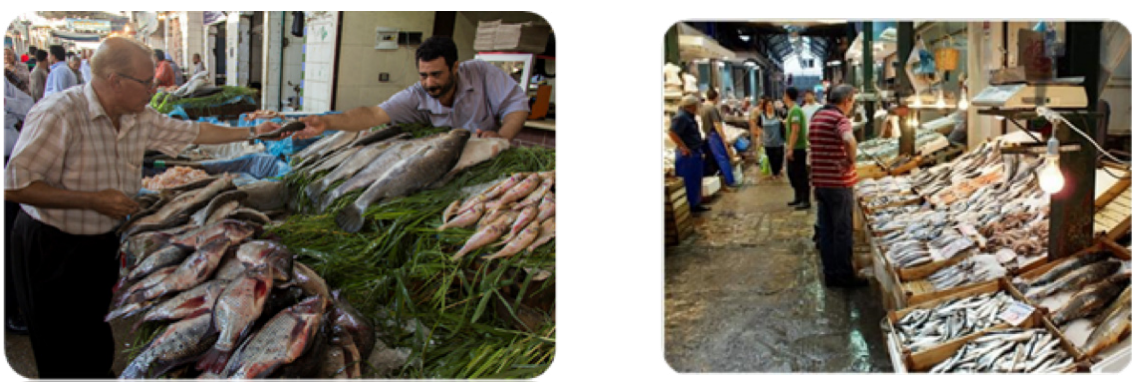

Figure 27: Fishing-derived Socio-economic Practices

Source: www.kafrelsheikh.gov.eg/invest/impoSector/clip_image028.png; www.kafrelsheikh.gov.eg/invest/impoSector/clip_image036.png/12 November 20171

Since 2014, Fish is the main dish in Kafr el-Sheikh, Kafr el-Sheikh people launched an initiative "Burullus Festival for Traditional Graffiti”. Festival was occurred annually (1 - 13 October). It was coordinated by Abd el-Wahab Abd el-Mohsen Foundation for Cultural Arts and Development. Foundation has been invited the Egyptian, international artists, and residents decorating the facades, of either the vernacular architectural buildings or the modern houses, the local shops and restaurants, and boats by the scenes of fish meals, the craft of fishing, and fish-derived miracles. ${ }^{40}$ Initiative was aimed at reviving the cultural identity, raising the sense of belonging and loyalty and also, respecting the cultural diversity.

\footnotetext{
${ }^{40}$ Heba Tullah Osman Abd Elrahim Zohny, "Mural Painting (Towards User Participation Philosophy)," in the 4th International Conference of the Faculty of Applied Arts, Helwan University (The 4th international Conference of the Faculty of Applied Arts, Helwan University, Giza, Egypt, 2016), 6-8, accessed January 13, 2018, www.conf.faa-design.com/pdf/50s.pdf.
} 

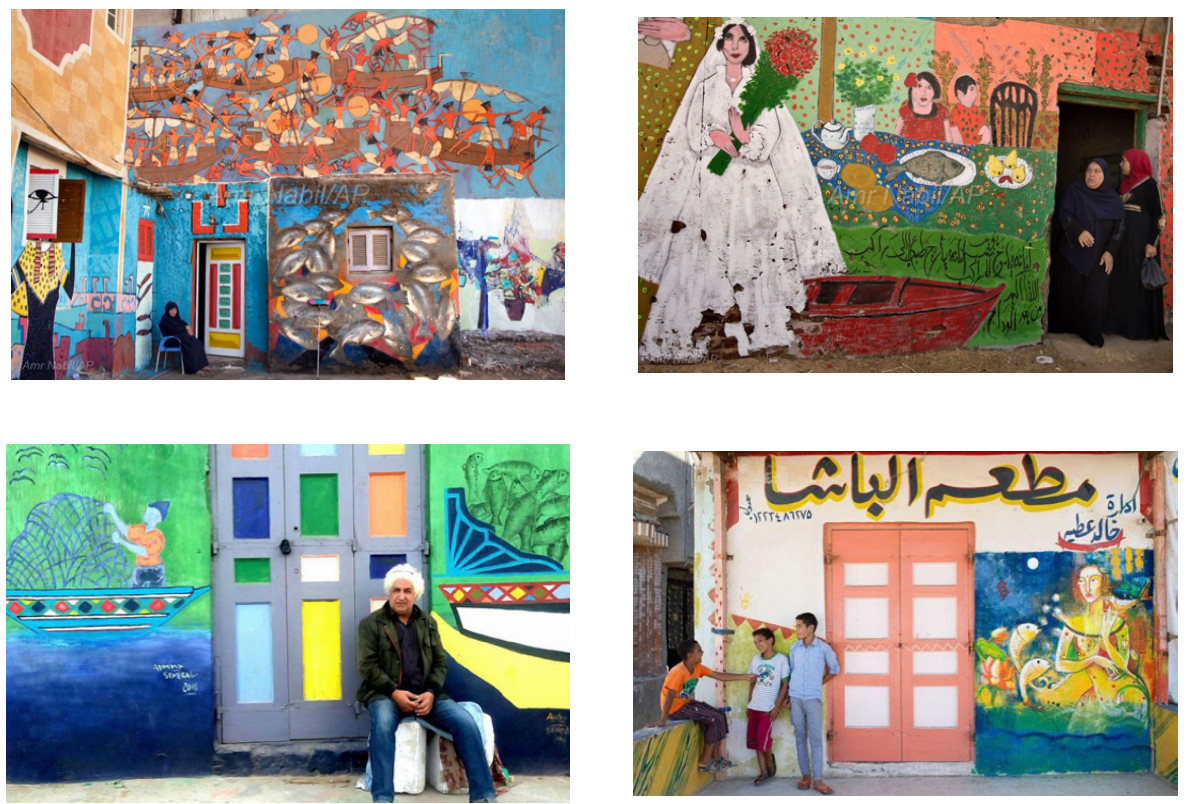

Figure 28: Artist Abd el-Wahab Abd el-Mohsen and Fishing-derived Art in Burullus

Source: (C)Ahmed Kafafi \& Amr Nabil photography. Paintings by Abdel Wahab Abdel El Mohsen Foundation for Culture, Arts and Development (http://bit. ly/2ySVoWL; http://bit.ly/2i6FD48; https://egyptianstreets.com/wp-content/uploads/2015/04/ct1.jpg) [Accessed November 12, 2017]

\section{Recommendations:}

After discussing these two case studies, the researcher presents some recommendations for the governmental authorities and the non-profit organizations, which are responsible for documenting, preserving and managing ICH in Egypt; as well as this regional heritage theme "MD". These recommendations are summarized in the following heritage managerial objectives developing the qualified context of preserving and sustaining this unique theme:

- $\quad$ Applying effectively the criteria of inscribing UNESCO ICH representatives

- Developing a legislative action that to recognize the international conventions of safeguarding ICH

- Creating a research and documentation project, in collaboration with the Mediterranean Diet Foundation, to preserve MD-derived practices in Egypt

- $\quad$ Presenting the popular dishes at the menu of the local, or touristic restaurant

- Cooperating with governmental and non-governmental entities to put directly MD at the action of the national sustainable developmentplan.

- $\quad$ Promoting nationally and internationally the popular MD-derived festive events

\section{Conclusion:}

In sum, a research was observed the great cultural significance of MD in Egypt. It has been clarified the great impact of reviving, operationalizing and sustaining MD on the sustainable development process supporting the national socio-economic context. MD theme is a good tool to raise the sense of respecting the cultural diversity. As well as, it has a supportive ability of securing the nutritional food system. 


\section{Bibliography}

Arizpe, Lourdes. "Singularity and Micro-Regional Strategies in Intangible Cultural Heritage." In Anthropological Perspectives on Intangible Cultural Heritage, edited by Lourdes Arizpe and Cristina Amescua, Vol. 6. Springer Briefs in Environment, Security, Development and Peace. New York: Springer and Centro Regional de Investigaciones, Universidad Nacional Autónoma de México, 2013.

BawabaNews. "Siwan Traditional Dance “Tajo Tajo.” Al Bawaba Video. https://youtu.be/xQeg3WO4fKo, 2017. Accessed April 30, 2017, https://youtu.be/xQeg3WO4fKo.

Culture. "Siwa Culture." Culture, 2017. Accessed October 10, 2017, www.siwaoasis.com/siwa_food.html.

Dernini, Sandro. "The Strategic Proposal for the Candidacy of the Mediterranean Diet for Inclusion in the UNESCO List of Intangible Cultural Heritage.” Academic. European Institute of the Mediterranean (IEMed.), 2008. Accessed September 18, 2017, www.iemed.org/anuari/2008/aarticles/EN288.pdf.

El Sheikha, A. F., R. Ray, D. Montet, S. Panda, and W. Worawattanamateekul. “African Fermented Fish Products in Scope of Risks.” International Food Research Journal 21, no. 1 (2014): 425-32.

El-Sebaiy, Laila A., and Samir M. Metwalli. "Changes in Some Chemical Characteristics and Lipid Composition of Salted Fermented Bouri Fish Muscle (Mugil Cephalus).” Food Chemistry 31, no. 1 (1989): 41-50.

Emirates National Media Council. Khalifa International Award for Date Palm and Agricultural Innovation. 7th ed. Abu Dhabi, United Arab Emirates: Emirates National Media Council, 2015. Accessed January 15, 2018, www.kiaai.ae/pdf/2016.pdf.

FAO. FAO and Traditional Knowledge: the Linkages with Sustainability, Food Security and Climate Change Impacts. Rome, Italy: Food and Agriculture Organization of the United Nation (FAO), 2009. Accessed November 16, 2017, www.fao.org/docrep/01 1/i0841e/i0841 e00.htm.

--_. Proposal for Designation as Globally Important Agricultural Heritage Site: Siwa Oasis, Egypt. Egypt: FAO, 2016. Accessed October 15, 2017, www.fao.org/3/a-bp825e.pdf.

Fundación Dieta Mediterránea. "The Mediterranean Diet Pyramid has Adapted to the New Way of Life." The Mediterranean Diet, 2010. Accessed November 22, 2017, http://mediterradiet.org/nutrition/ mediterranean_diet_pyramid.

“The Mediterranean Diet Pyramid.” The Mediterranean Diet, 2010. Accessed November 19, 2017, http:// mediterradiet.org/dietamed/piramide_INGLES.pdf.

Hassan-Wassef, Habiba. "Food Habits of the Egyptians: Newly Emerging Trends." La Revue de Santé de La Méditerranée Orientale 10, no. 6 (December 2004): 898-915.

Kantor, Paula, Froukje Kruijssen, Malcolm Dickson, and Ihab Anwar. Informal Fish Retailing in Rural Egypt: Opportunities to Enhance Income and Work Conditions for Women and Men. Penang, Malaysia: World Fish, 2014. Accessed November 11, 2017, http://pubs.iclarm.net/resource_centre/2014-51.pdf. Lacirignola, Cosimo, Roberto Capone, Hamid El-Bilali, Sandro Dernini, Barbara Burlingame, and Alexandre Meybeck. Mediterranean Food Consumption Patterns: Diet, Environment, Society, Economy and Health. Edited by Rekia Belahsen, Elliot Berry, Denis Lairon, F. Xavier Medina, Yousseph Aboussaleh, Gulden Pekcan, Antonia Trichopoulou, and Lluìs Serra Majem. Rome, Italy: Food and Agriculture Organization of the United Nation (FAO) and International Center for Advanced Mediterranean Agronomic Studies (CIHEAM), 2005. Accessed November 19, 2017, www.fao.org/3/a-i4358e.pdf.

Machuca, Jesús Antonio. "Challenges for Anthropological Research on Intangible Cultural Heritage." In Anthropological Perspectives on Intangible Cultural Heritage, edited by Lourdes Arizpe and Cristina Amescua, Vol. 6. Springer Briefs in Environment, Security, Development and Peace. New York: Springer and Centro Regional de Investigaciones, Universidad Nacional Autónoma de México, 2013. 
Montella, Massimo. "Cultural Value.” In Cultural Heritage and Value Creation: Towards New Pathways, edited by Gaetano M. Golinelli. London: Springer, 2015.

Padilla, Martine, Zahra S. Ahmed, and Habiba H. Wassef. "In the Mediterranean Region: Overall Food Security in Quantitative Terms but Qualitative Insecurity?” Analytic Note. Paris, France: International Center for Advanced Mediterranean Agronomic Studies (CIHEAM), 2005. Accessed May 20, 2017, http://portail2.reseau-concept. net/Upload/ciheam/fichiers/ANP4.pdf.

Petrillo, Pier Luigi. "Cultural Relevance and Promotion Opportunities for the Agro-Food Traditions: The Mediterranean Diet One Year after and the Role of UNESCO.” Mediterranean Diet Forum in Imperia, 2010. Accessed September 17, 2017, www.promimperia.it/media/11311/wg1_1_eng_coordinator_petrillo_ mediterranean_diet_as_world_heritage.pdf.

-_-. "The Mediterranean Diet One Year after and the Role of UNESCO.” Italian Committee. The Special Agency PromImperia- The Italian Chamber of Commerce Committee, 2014. Accessed September 17, 2017, www.promimperia.it/media/11311/wg1_1_eng_coordinator_petrillo_mediterranean_diet_as_world_ heritage.pdf.

Petruccioli, Attilio, and Calogero Montalbano, eds. Actions for a Sustainable Development: Siwa Oasis. Bari, Italy: Dipartimento di Ingegneria civile e Architettura, 2011.

Rennaa, Massimiliano, VitoAntonio Rinaldib, and Maria Gonnellaa. “The Mediterranean Diet between Traditional Foods and Human Health: The Culinary Example of Puglia (Southern Italy).” International Journal of Gastronomy and Food Science 2 (2015): 63 - 71.

Scepi, Giovanni, and Pier Luigi Petrillo. "The Cultural Dimension of the Mediterranean Diet as an Intangible Cultural Heritage of Humanity." In Cultural Heritage and Value Creation: Towards New Pathways, edited by Gaetano M. Golinelli. London: Springer, 2015.

Scovazzi, Tullio. "Intangible Cultural Heritage as Defined in the 2003 UNESCO Convention." In Cultural Heritage and Value Creation: Towards New Pathways, edited by Gaetano M. Golinelli. London: Springer, 2015.

Turmo, Isabel González. “The Mediterranean Diet as a Heritage Object.” Quaderns de La Mediterrània 13 (2010): 45-49.

UNESCO. Convention for the Safeguarding of the Intangible Cultural Heritage, MISC/2003/CLT/CH/14 § (2003). Accessed October 22, 2017, http://unesdoc.unesco.org/images//0013/001325/132540e.pdf. UNESCO ICH. “Decision of the Intergovernmental Committee: Mediterranean Diet (8.COM 8.10).”. UN, 2013. Accessed August 18, 2017, https://ich.unesco.org/en/decisions/8.COM/8.10.

--_. "Mediterranean Diet." UNESCO Intangible Cultural Heritage Committee, 2013. Accessed August 12, 2017, https://ich.unesco.org/en/RL/mediterranean-diet-00884.

-_-. "Procedure of Inscription of Elements on the Lists and of Selection of Best Safeguarding Practices." Organization. UNESCO Intangible Cultural Heritage Committee, 2003. Accessed August 18, 2017, https://ich. unesco.org/en/procedure-of-inscription-00809.

Vale, Margaret M. Siwa: Jewelry, Costume, and Life in an Egyptian Oasis. 1st ed. Cairo: The American University in Cairo Press, 2015.

Zohny, Heba Tullah Osman Abd Elrahim. "Mural Painting (Towards User Participation Philosophy)." In The 4th International Conference of the Faculty of Applied Arts, Helwan University. Giza, Egypt, 2016. Accessed January 01, 2018, www.conf.faa-design.com/pdf/50s.pdf. 


\title{
Marketing Planning as a Tool to Augment the Visitation of Heritage Sites and Museums ${ }^{1}$
}

\author{
Mohamed Amer ${ }^{2}$
}

\begin{abstract}
Heritage, either tangible or intangible, is considered a tool for preserving the inherited past, which forms the present identity, into the distant future for the new generations. Regarding our current socio-cultural needs, the word "Heritage" contributes promoting the image of cultural landscapes, heritage sites, or museums. These heritage attractions are the places where the people can realize the past and communicate emotionally with the heritage area. This paper views the concept of heritage marketing as a process augmenting the visitation of cultural landscapes, heritage sites, or museums. At the same time, it compiles a couple of marketing techniques strengthening the visitor's satisfaction, within the appropriate offered programs, via selecting the exact target audience. After reviewing the literature, it was found out that heritage marketing is focused on promoting and representing the values of heritage attractions, while there is no main structure or a developed framework for the marketing plan of cultural heritage destinations. As a result, this research aims to fill in this academic and professional gap interpreting the main steps of heritage marketing plan.
\end{abstract}

\section{Keywords}

Heritage Management - Heritage Sites - Museums - Heritage Economic - Heritage Marketing

\section{Introduction}

According to UNESCO World Heritage Center, "a site's inscription on the World Heritage List often coincides with a boost in visitation rates" 3 . Although there are heritage attractions which are inscribed in World Heritage List (WHL), these sites, as well as another heritage sites and museums in general, apparently are not well promoted. So, the absence of planned marketing techniques resulted in not only the decreased market position of the heritage sites and museums but their overall image as well. Consequently, the number of visitors becomes a great challenge as the site could suffer acute decrease in revenues necessary for both its preservation and sustainability; and therefore, to loss the integrity and authenticity.

This paper is probably among the first attempts to address the plan of marketing in the heritage sites and museums in general. Although there are few published researches in relation to this perspective "Heritage Marketing", there are some authors who have generally been writing about it and its methods such as Shashi Misiura (2006); Neil G. Kotler, Philip Kotler, and Wendy I. Kotler (2008); and Hyung Yu Park (2014).

This developed structure of heritage marketing plan has an appropriate significance. It promotes the site's culture significance augmenting the visitation rate especially during off-peak times; managing a demand; as well as avoiding adverse impacts on the heritage site or museum.

\footnotetext{
${ }^{1}$ This paper was divided from a dissertation of Master of Arts in Heritage Conservation and Site Management, that has jointly been held between Helwan University (Egypt) and Brandenburg University of Technology Cottbus-Senftenberg (Germany), "Developing Innovative Marketing Plan to Augment the Visitation of Egyptian World Heritage Sites: A Case Study on Saladin Citadel'. In order to review the whole heritage marketing project, let's go to this link (www.researchgate.net/publication/291832778)

${ }^{2}$ Heritage Management Professional and Founder of “HeritageForAll” Initiative (mohammadbadry2013@gmail.com)

${ }^{3}$ Arthur Pedersen, Managing Tourism at World Heritage Sites: a Practical Manual for World Heritage Site Managers, vol. WH Manuals 1 (Paris: UNESCO WHC, 2002), accessed June 26, 2015, http://whc.unesco.org/uploads/activities/documents/activity-1132-.pdf.
} 